\title{
Early and Middle Jurassic mires of Bornholm and the Fennoscandian Border Zone: a comparison of depositional environments and vegetation
}

\author{
Henrik I. Petersen, Lars H. Nielsen, Eva B. Koppelhus and Henning S. Sørensen
}

Suitable climatic conditions for peat formation existed during Early-Middle Jurassic times in the Fennoscandian Border Zone. Autochthonous peat and allochthonous organic matter were deposited from north Jylland, south-east through the Kattegat and Øresund area, to Skåne and Bornholm. The increase in coal seam abundance and thickness from north Jylland to Bornholm indicates that the most favourable peat-forming conditions were present towards the south-east. Peat formation and deposition of organic-rich muds in the Early Jurassic coastal mires were mainly controlled by a continuous rise of relative sea level governed by subsidence and an overall eustatic rise. Watertable rise repeatedly outpaced the rate of accumulation of organic matter and terminated peat formation by lacustrine or lagoonal flooding. Organic matter accumulated in open-water mires and in continuously waterlogged, anoxic and periodically marine-influenced mires. The latter conditions resulted in huminite-rich coals containing framboidal pyrite. The investigated Lower Jurassic seams correspond to peat and peaty mud deposits that ranged from $0.5-5.7 \mathrm{~m}$ in thickness, but were generally less than $3 \mathrm{~m}$ thick. It is estimated that on Bornholm, the mires existed on average for $c .1200$ years in the Hettangian-Sinemurian and for $c .2300$ years in the Late Pliensbachian; the Early Jurassic (Hettangian-Sinemurian) mires in the Øresund area existed for $c .1850$ years. Aalenian uplift of the Ringkøbing-Fyn High and major parts of the Danish Basin caused a significant change in the basin configuration and much reduced subsidence in the Fennoscandian Border Zone during the Middle Jurassic. This resulted in a more inland position for the Middle Jurassic mires which on occasion enabled peat accumulation to keep pace with, or temporarily outpace, watertable rise. Thus, peat formation was sometimes sustained for relatively long periods, and the mires may have existed for up to 7000 years in the Øresund area, and up to 19000 years on Bornholm. The combination of the inland position of the mires, a seasonal climate, and on occasion a peat surface above groundwater level caused temporary oxidation of the peat surfaces and formation of inertinite-rich coals. The spore and pollen assemblages from coal seams and interbedded siliciclastic deposits indicate that the dominant plant groups in both the Early and Middle Jurassic mires were ferns and gymnosperms. However, significant floral differences are evident. In the Lower Jurassic coals, the palynology testifies to a vegetation rich in cycadophytes and coniferophytes (Taxodiaceae family) whereas club mosses were of lesser importance. Conversely, in the Middle Jurassic coals, the palynology indicates an absence of cycadophytes, a minor proportion of coniferophytes (Taxodiaceae) and a significant proportion of club mosses. These variations are probably related to adaptation by different plants to varying environmental conditions, in particular of hydrological character.

Keywords: Danish Basin, Fennoscandian Border Zone, Bornholm, Lower-Middle Jurassic, coal distribution, coal petrography, sedimentology, palynology, mire environments, mire vegetation, peat accumulation rates, sea-level change

H.I.P., L.H.N., E.B.K.* \& H.S.S.**, Geological Survey of Denmark and Greenland, Geocenter Copenhagen, Øster Voldgade 10, DK-1350 Copenhagen K, Denmark. E-mail: hip@geus.dk

Present addresses: "Royal Tyrrell Museum of Paleontology, Box 7500, Drumbeller TO7 OYO, Canada. **Danfoss A/S, L7-S38, DK-6430 Nordborg, Denmark. 
In contrast to the Permo-Carboniferous and Cenozoic, the Jurassic is not considered to be a time of major peat formation. However, the Jurassic succession of Northwest Europe, and in particular the Middle Jurassic, contains significant coal-bearing strata showing that favourable conditions for peat formation were fulfilled at many times. In the Danish area, coal-bearing strata are generally restricted to the Central Graben in the North Sea and the Fennoscandian Border Zone. Well-developed Lower-Middle Jurassic coals are found from the Øresund area to the island of Bornholm in the Baltic Sea indicating climatic and geological conditions suitable for the accumulation and preservation of organic matter (Fig. 1).

The importance of coal beds in stratigraphic analysis is emphasised by the fact that coal seams may represent a considerable proportion of the time represented by coal-bearing successions. Thus, this paper views the peat-forming environments on Bornholm and in the Fennoscandian Border Zone in a broad geological perspective and discusses the variability in peat-forming conditions in the area in an attempt to explain the principal compositional differences between the Lower and Middle Jurassic coal seams. In addition, the paper pre- sents palynological data from the coals and adjacent sediments and discusses the palynological evidence of the peat-forming vegetation compared to the evidence from the coal composition.

\section{Geological setting}

The Fennoscandian Border Zone is a major tectonic structure that separates the Baltic Shield from the Danish Basin and Polish Trough (Fig. 1). The border zone is divided into the stable Skagerrak-Kattegat Platform and the highly block-faulted Sorgenfrei-Tornquist Zone, which has been tectonically active at least since late Palaeozoic times (Sorgenfrei \& Buch 1964; Norling \& Bergström 1987; EUGENO-S Working Group 1988; Michelsen \& Nielsen 1991, 1993; Mogensen 1994). Towards the south-east, the Sorgenfrei-Tornquist Zone continues into the Teisseyre-Tornquist Zone via the Rønne Graben, west of Bornholm in the Baltic Sea. The Rønne Graben pull-apart basin was formed by Late Carboniferous - Early Permian dextral wrench-faulting (Vejbæk 1985; Liboriussen et al. 1987). Continued Triassic

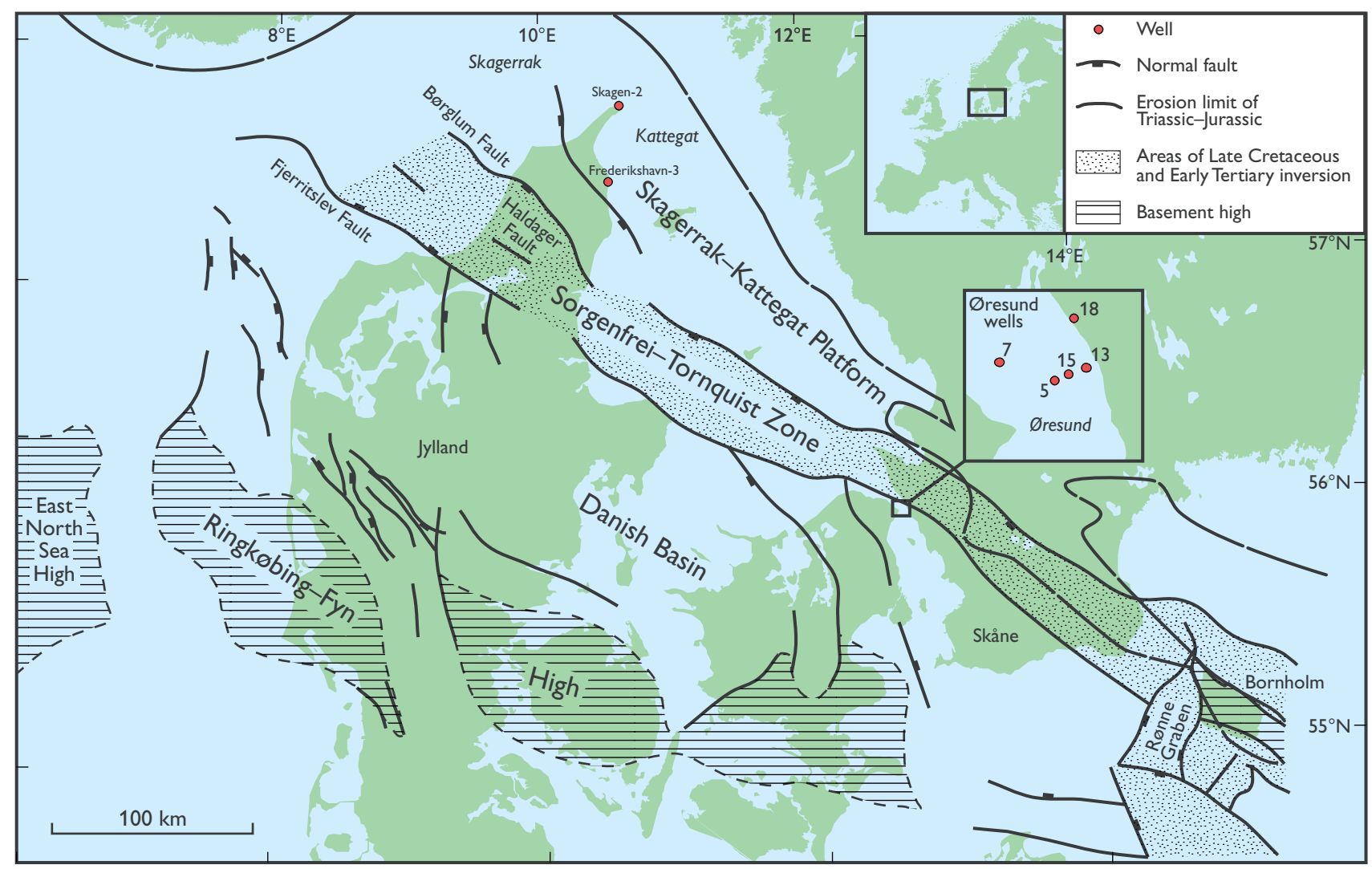

Fig. 1. Map showing the structural outline of the Fennoscandian Border Zone and the location of Bornholm and the Øresund, Skagen-2 and Frederikshavn-3 wells. Modified from Liboriussen et al. (1987) and EUGENO-S Working Group (1988). 
- Early Cretaceous wrench faulting resulted in faultcontrolled subsidence and tilting of fault blocks in the Sorgenfrei-Tornquist Zone. Compressional tectonism in the Late Cretaceous - Palaeogene led to inversion of fault blocks in the Sorgenfrei-Tornquist Zone and regional Neogene-Pleistocene uplift resulted in erosion of the Mesozoic sediments (Gry 1969; Michelsen \& Nielsen 1991, 1993; Japsen 1993; Petersen et al. 2003, this volume).

Northwards transgression from the Tethys during Early Jurassic times due to an overall rise in sea level combined with continued subsidence of the North Sea area and the Danish Basin, created an extensive epicontinental sea in Northwest Europe (Hallam 1988, 1992; Ziegler 1988). The north-eastern margin of the sea coincided with the Fennoscandian Border Zone. Coastal and delta plains were established along the margin of the sea, and Hettangian-Sinemurian coal-bearing strata were deposited on Bornholm (Rønne Formation), in the Øresund area, Skåne (Helsingborg Member), and in the Kattegat and north Jylland (Gassum Formation; Troedsson 1951; Gry 1969; Bertelsen 1978; Gravesen et al. 1982; Piénkowski 1991; Petersen 1993, 1994; Nielsen 1995; Surlyk et al. 1995).

Fully marine conditions were established across the entire area in the Early Pliensbachian, but due to a Late Pliensbachian regression, deposition of coal-bearing strata (Sorthat Formation) was resumed on Bornholm until an Early Toarcian transgression terminated peat formation (Fig. 2-3; Koppelhus \& Nielsen 1994; Petersen \& Nielsen 1995). In the Danish Basin, deposition of marine clays and sands continued until the Aalenian (Michelsen 1989; Michelsen \& Nielsen 1991; Nielsen 1995).

Continental conditions were re-established during the Middle Jurassic and coal-bearing strata were deposited in lake-dominated peatlands and small alluvial fans on Bornholm (Bagå Formation; Gry 1969; Gravesen et al. 1982; Petersen 1993; Koppelhus \& Nielsen 1994), in lake-dominated peatlands in the Øresund area (Petersen 1994), and in deltaic environments in Skåne (Fuglunda Member; Rolle et al. 1979; Norling et al. 1993). Thin coaly muds, lacustrine clays and fluvial sands were deposited in north Jylland (Haldager Sand Formation; Koch 1983; Nielsen 1995).

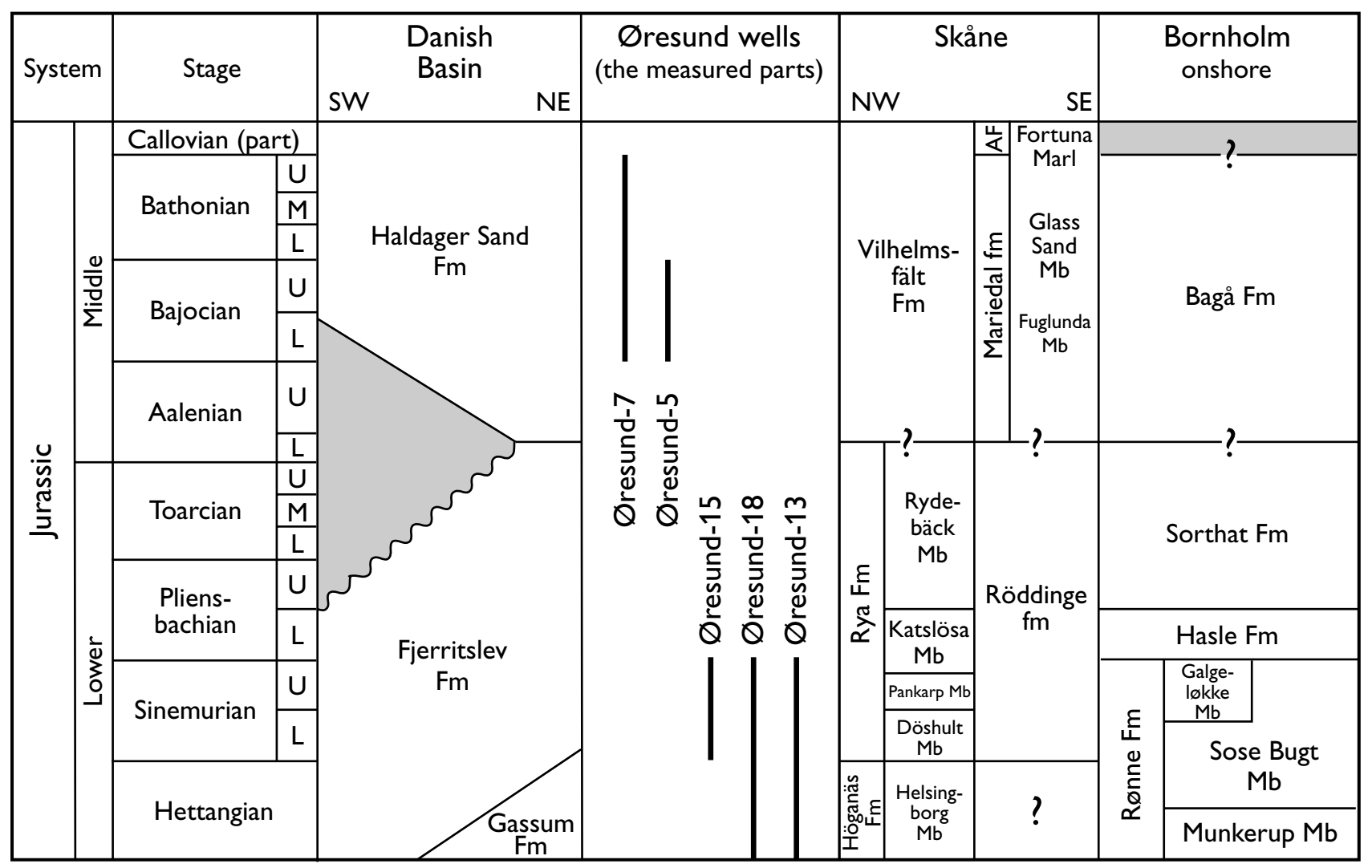

Fig. 2. The Lower and Middle Jurassic stratigraphy in the study area; AF, Annero Fm. Compiled from Michelsen (1978), Gravesen et al. (1982), Sivhed (1984), Ahlberg et al. (2003, this volume) and Michelsen et al. (2003, this volume). Note that the age range of the Øresund-5 and -7 wells is poorly constrained. 


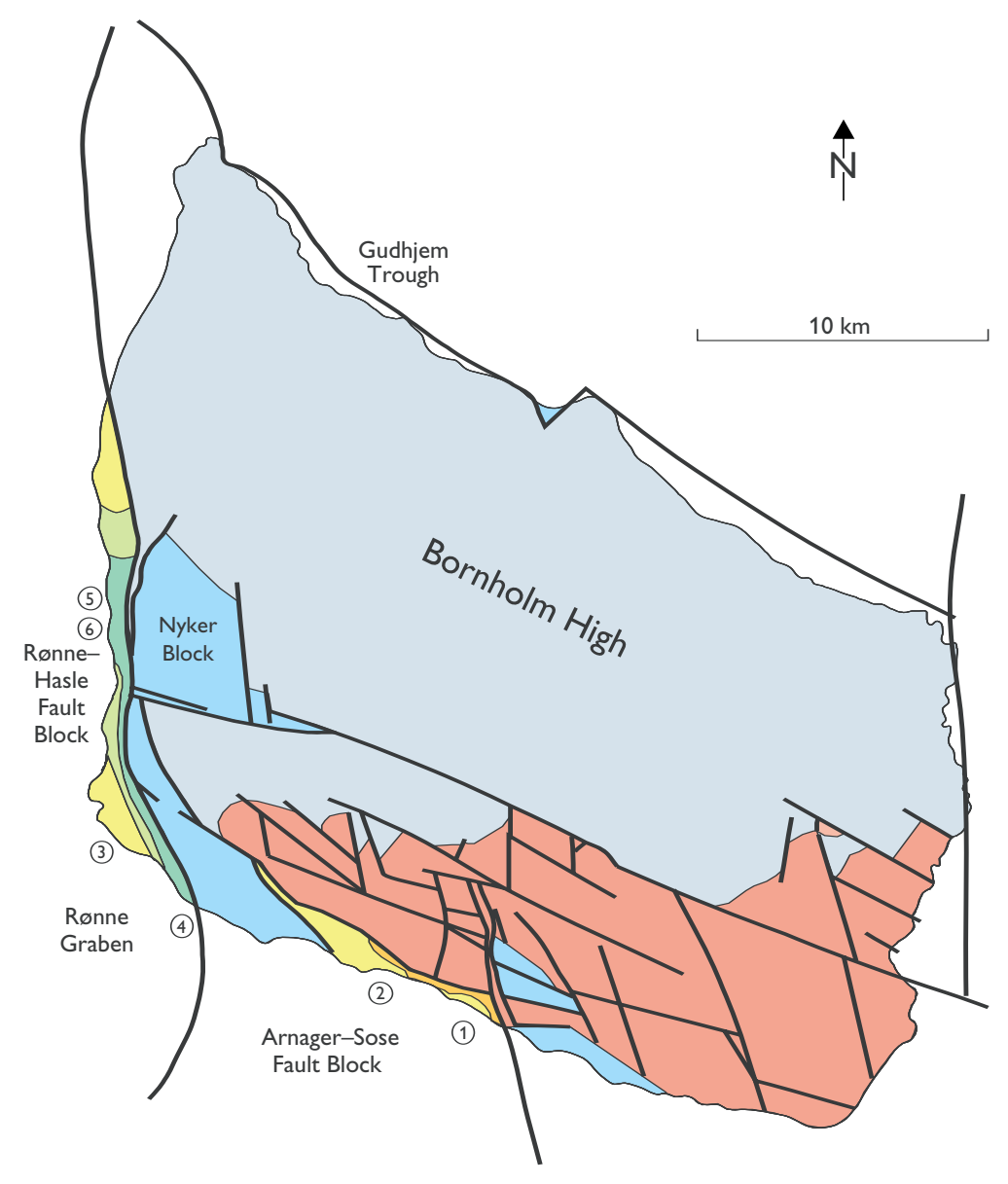

Fig. 3. Geological map of Bornholm showing the location of the studied localities: 1, coastal exposures, Munkerup Member; 2, Sose Bugt succession, Sose Bugt Member; 3, Galgeløkke cliff succession, Galgeløkke Member; 4, Korsodde coastal cliff, Sorthat Formation; 5, Levka-1 well, Sorthat Formation; 6, Hasle Klinkerfabrik Clay Pit, Bagå Formation. Modified from Gravesen et al. (1982).

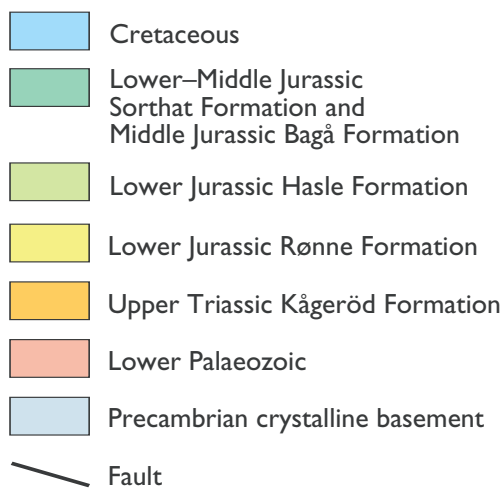

\section{Early-Middle Jurassic climate}

Establishment of peat-forming mires and preservation of peat are mainly controlled by a complex interaction of climate, subsidence and eustasy. The breakup of Pangea and northwards drift of Laurasia during the Mesozoic into a warm-temperate to subtropical climatic zone at approximately $40^{\circ} \mathrm{N}$, and the creation of a large epicontinental sea in northern Europe in the Jurassic, resulted in a substantial increase in humidity and rainfall compared to the hot and arid conditions that had dominated the Permian and most of the Triassic periods (Parrish et al. 1982; Ziegler 1982; Hallam 1984; Scotese 1994). The interaction of precipitation and temperature, and in particular seasonality of rainfall, has a strong influence on peat formation, because probably the single most important factor controlling peat distribution is continuity in rainfall (Ziegler et al. 1987; Calder \& Gibling 1994; Lottes \& Ziegler 1994). Seasonally wet conditions north of Tethys (western Europe) in
Jurassic times has been suggested by Hallam (1985), and reconstructed rainfall maps for the Pliensbachian suggest a moderate rainfall in the Danish region (Parrish et al. 1982).

Plant fossil assemblages from the Rhaetian and Lower Jurassic of Sweden, Germany, Bornholm and Jameson Land, East Greenland, indicate that the climate was sufficiently uniform to establish a northern floral province with relatively uniform plant communities (Harris 1937; Florin 1958). Warm conditions are suggested by the large number of plant species from Jameson Land, and thin cutinised leaves of Podozamites and Equisetales comparable in size to modern subtropical bamboos are thought to reflect favourable conditions for plant growth (Harris 1937). Investigations of clay mineralogy and palaeosols of the Jurassic on Bornholm indicate a warm, humid climate (Graff-Petersen \& Bondam 1963; Arndorff 1993), and the taxonomic composition of miospore assemblages from the Hettangian-Sinemurian Sose Bugt section on Bornholm lends support to the interpretation 


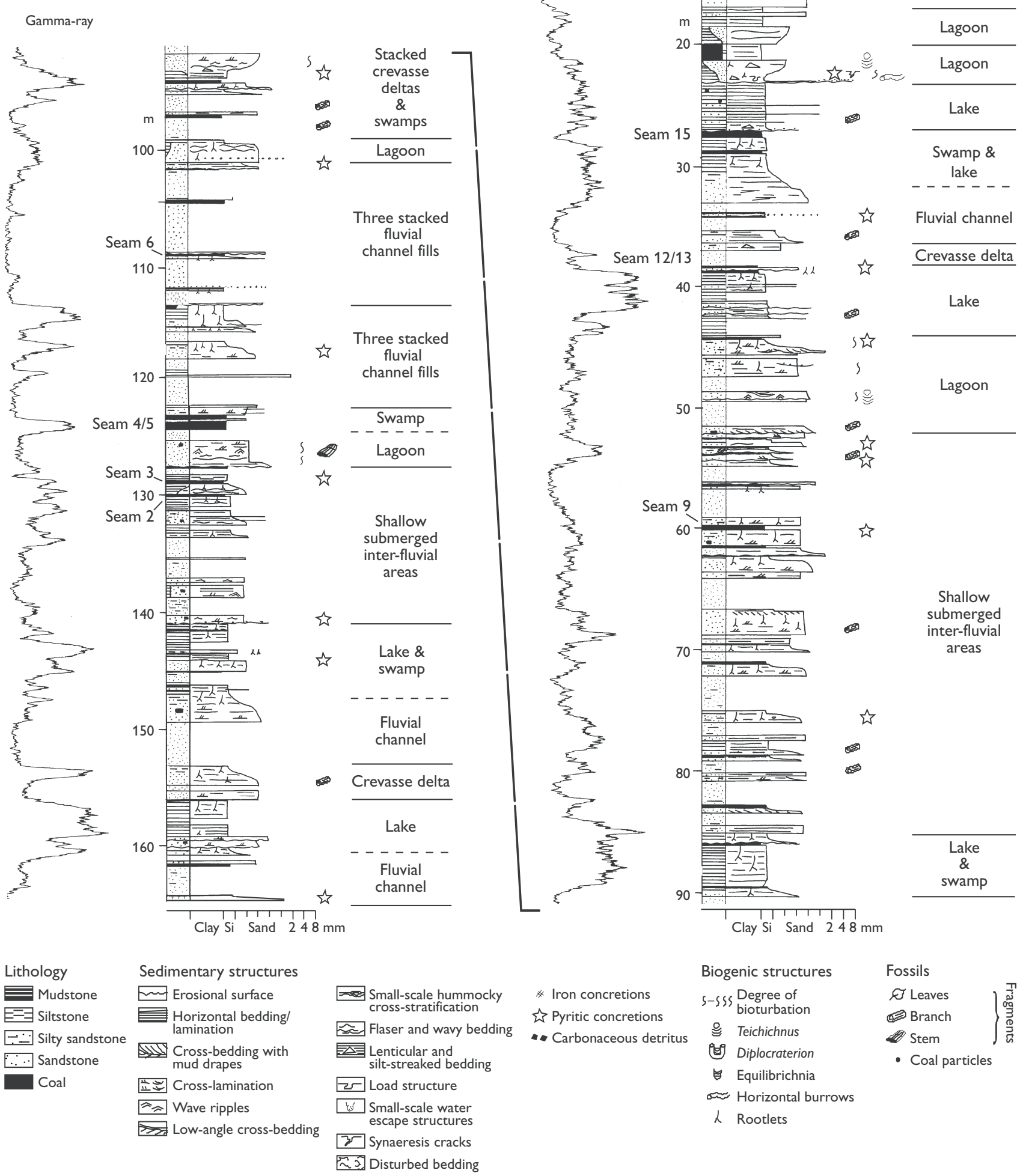

Fig. 4. Sedimentological core-log of the Upper Pliensbachian - Lower Toarcian part of the Sorthat Formation in the Levka-1 well (reference level: metres below surface). The investigated coal seams are indicated. The accompanying legend refers also to Figs 5 , $10,11,14,15$. Intervals with no core recovery (lithology shown only) are interpreted on the basis of gamma-log data. Modified from Koppelhus \& Nielsen (1994). 

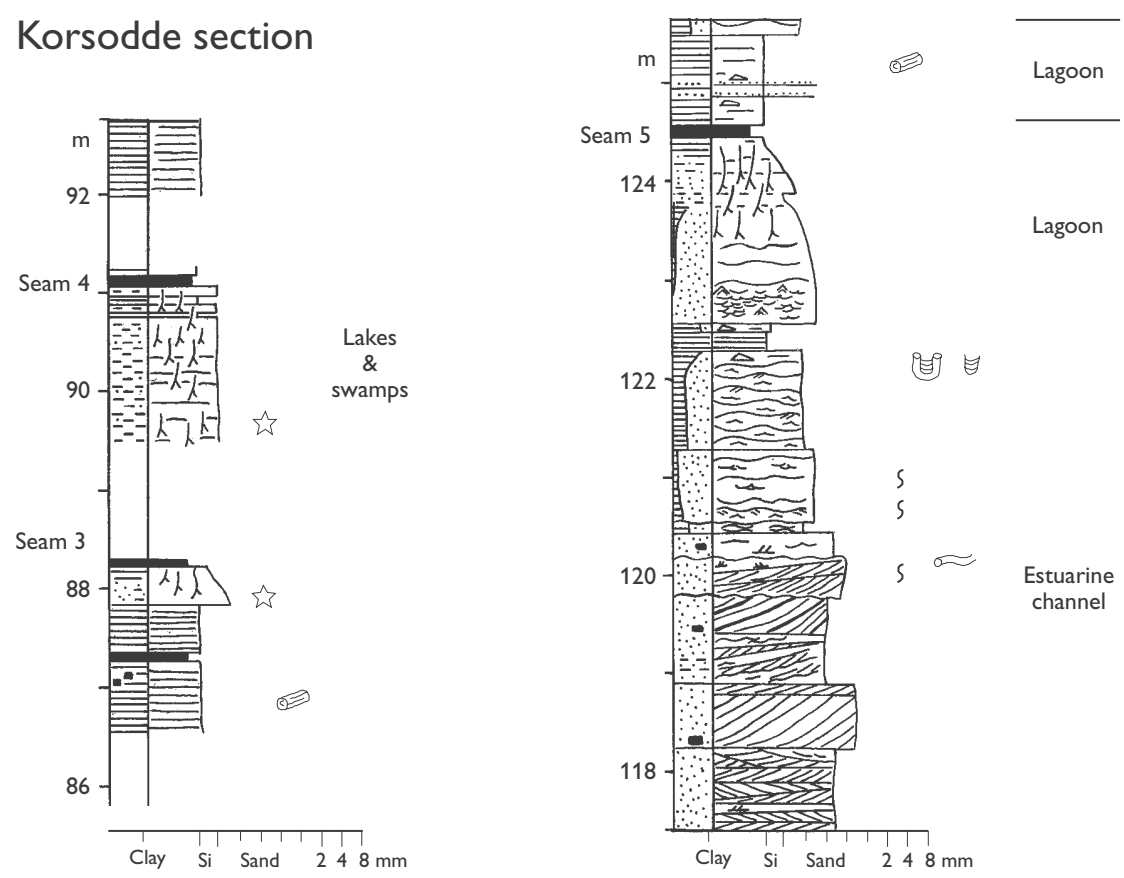

Fig. 5. Sedimentological log of selected coal-bearing intervals from the Korsodde coastal cliff succession (Sorthat Formation); reference level: metres above base of section. Modified from Koppelhus \& Nielsen (1994); for legend, see Fig. 4.

of a wetter climate, in particular compared to areas further to the west, for example around the British Isles (Batten et al. 1994). However, seasonal variations are indicated by annual rings in tree trunks from the Rhaetian of Skåne (Ahlberg \& Arndorff 1994), in gymnospermous wood from Jameson Land (Harris 1937), and in tree-stumps from the Hettangian and Bajocian-Bathonian on Bornholm (Höhne 1933; Nielsen 1995; Surlyk et al. 1995). Parts of the Hettangian-Sinemurian succession in the Øresund-18 and -15 wells are characterised by thinly-stratified light grey silty claystones and dark grey claystones or thin graded layers with a silty base and a darker, more clayey upper part. The thin layering may reflect seasonal fluctuations in sedimentation rates, possibly due to unevenly distributed rainfall through the year, as suggested by Hamilton \& Tadros (1994) for similar stratified lacustrine mudstones with coal seams in the Gunnedah Basin, Australia.

\section{Lower Jurassic coal-bearing strata}

\section{Sorthat Formation, Bornholm}

Fully marine conditions prevailed in early Jurassic times over most of the Danish Basin (Michelsen 1975). On Bornholm, however, coastal plain environments lasted until the Late Sinemurian; a transgression caused deposition of marine sandstones in the Early Pliensbachian (Gravesen et al. 1982; Surlyk et al. 1995). A Late Pliens- bachian regression re-established a coastal plain environment with peat-forming mires on Bornholm until the regional Early Toarcian sea-level rise caused a renewed transgression (Koppelhus \& Nielsen 1994). The Upper Pliensbachian - Lower Toarcian sediments of the Levka-1 well and the lower part of the Korsodde section (included in the Sorthat Formation) were deposited in an overall coastal plain environment (Figs 3-5; Koppelhus \& Nielsen 1994; Petersen \& Nielsen 1995; Michelsen et al. 2003, this volume). The Levka-1 well section represents fluvial channels, floodplain areas with shallow lakes and lagoons, and small crevasse deltas (Fig. 4). Coalified wood fragments and stems occur frequently. Coal seams 2, 3, 6 and 9 represent peat-forming mires established on top of abandoned sandy channel fills and on heavily rooted crevasse and lake deposits in shallow inter-fluvial areas. Seams 4 and 5 represent peat accumulation on top of lagoonal sediments showing wave-ripples, wavy and flaser bedding, bioturbation and transported Equisetites stems. A well-oxidised palaeosol that developed upon the fill of a coastal lake, is overlain by seams 12 and 13 which are separated by a thin sandy, rooted parting. The clay of the lake-fill contains a palynomorph assemblage dominated by spores and pollen, together with a few acritarchs and Tasmanites. Seam 15 is interpreted to represent an infilled-lake peat mire.

The lower $133 \mathrm{~m}$ of the Korsodde section consists of fluvial channel sand interbedded with heterolithic fining-upwards units of clay and silt and laminated to 
almost massive clay beds topped by coal seams that overlie rooted horizons (Fig. 5). The fining-upwards units contain pyrite nodules, coalified wood fragments, and mixed palynomorph assemblages of spores, pollen, acritarchs, freshwater algae and marine dinoflagellate cysts, and were deposited in small coastal lakes and protected lagoons (Batten et al. 1994; Koppelhus \& Nielsen 1994).

\section{Coal seam composition and peat-forming environments}

The studied coal seams of the Sorthat Formation are between 0.08 and $0.57 \mathrm{~m}$ thick (Figs 4, 5). Those from the Levka-1 well and seam 4 from the Korsodde sec-

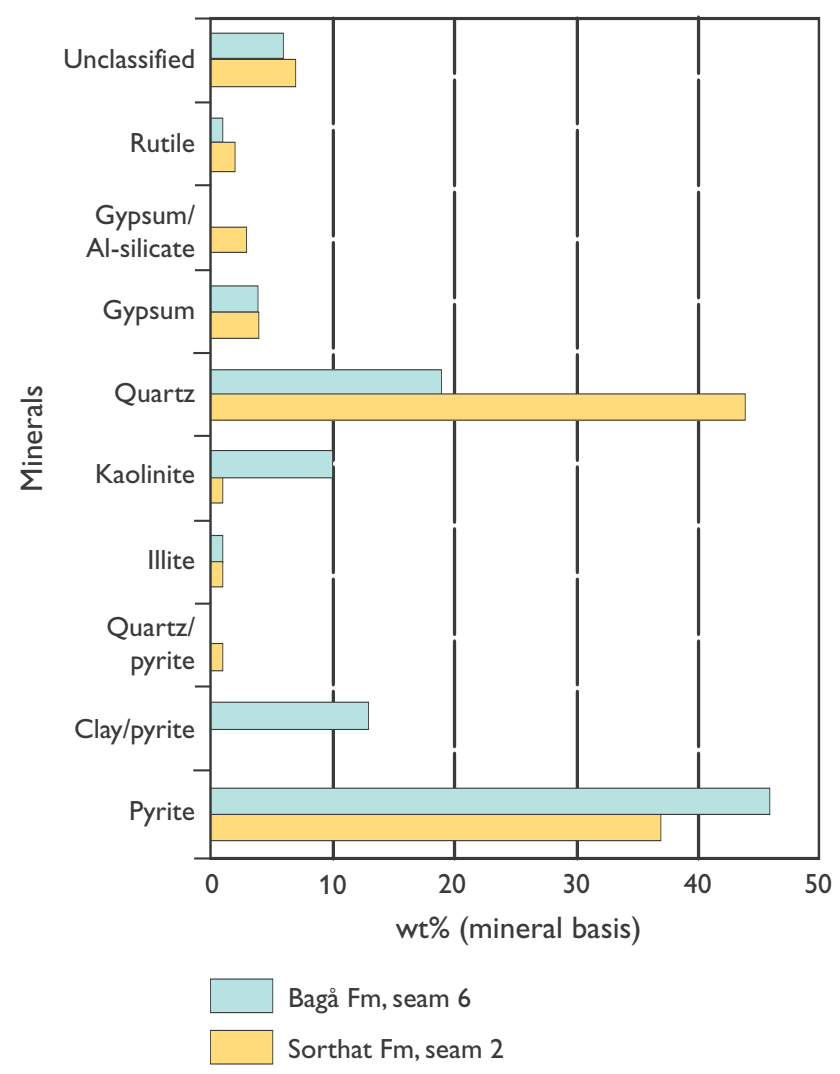

Fig. 6. Composition (wt $\%$ on a mineral basis) of the mineral matter in the upper part of seam 2, Sorthat Formation (Levka-1 well) and in seam 6 (interval 125-135 cm) in the upper Bagå Formation. The group 'unclassified' includes minerals which constitute less than $1 \mathrm{wt} \%$ of the inorganic fraction. tion are dominated by very high contents of huminite (seam-average ranges from 80-90 vol.\%), and only minor amounts of inertinite, liptinite and minerals (Petersen \& Nielsen 1995). Pyrite occurs in several of the seams. Seams 3 and 5 from the Korsodde section differ in petrographic composition from the rest of the investigated seams. Seam 3 contains significant amounts of minerals (seam-average $37 \mathrm{vol} . \%$ ) and seam 5 contains a high proportion of inertinite (seam-average 30 vol.\%). Both seams contain pyrite.

Reflected-light microscopic analysis of a sample from seam 2 in Levka-1 reveals that it contains 2 vol.\% pyrite and 6 vol.\% of other minerals (Petersen \& Nielsen 1995). The composition of the inorganic components in the sample was further investigated by computer controlled scanning electron microscopy (CCSEM). Inorganic par-

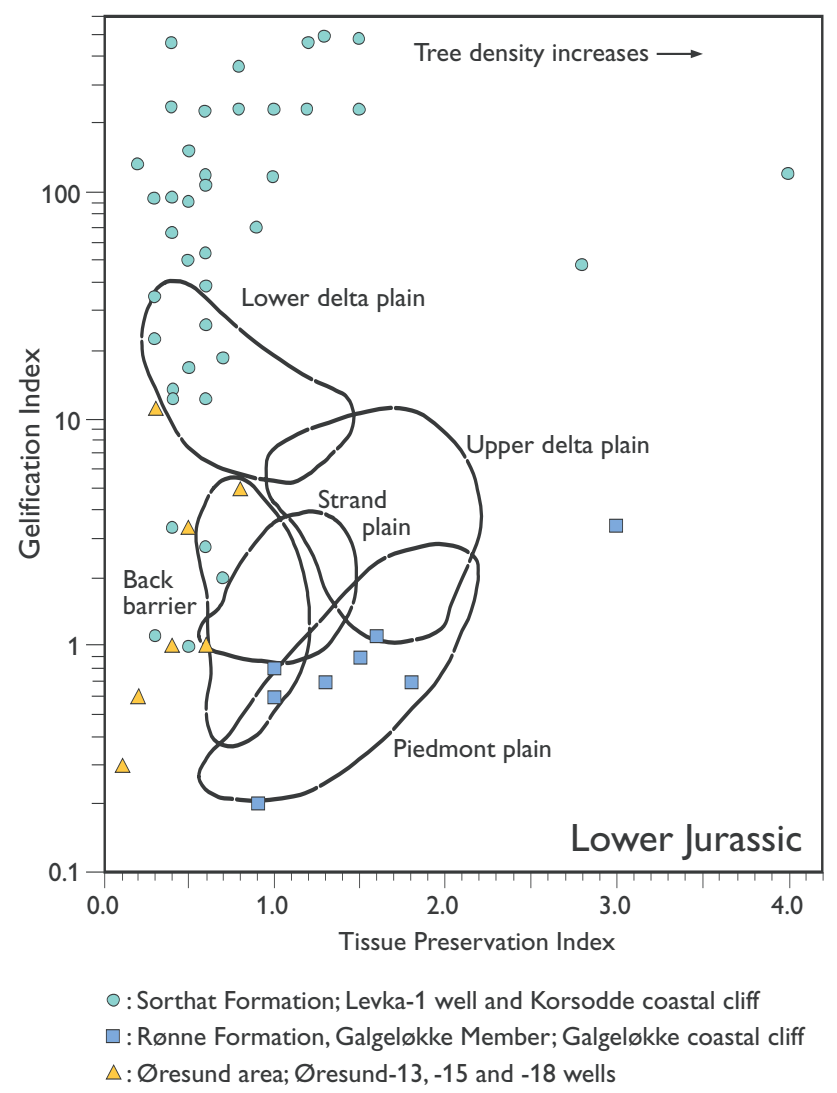

Fig. 7. Coal samples from the Lower Jurassic of Bornholm and the Øresund area plotted on the Tissue Preservation Index (TPI) vs. Gelification Index (GI) diagram of Diessel (1986). The strand plain area is after Kalkreuth \& Leckie (1989; see also Diessel 1992). Notable are the low GI values of the Galgeløkke Member coal suggesting oxidizing conditions during deposition of the peat (domed bog), and the very high GI values of the Upper Pliensbachian Lower Toarcian Sorthat Formation coals suggesting anoxic, waterlogged conditions during peat deposition. 

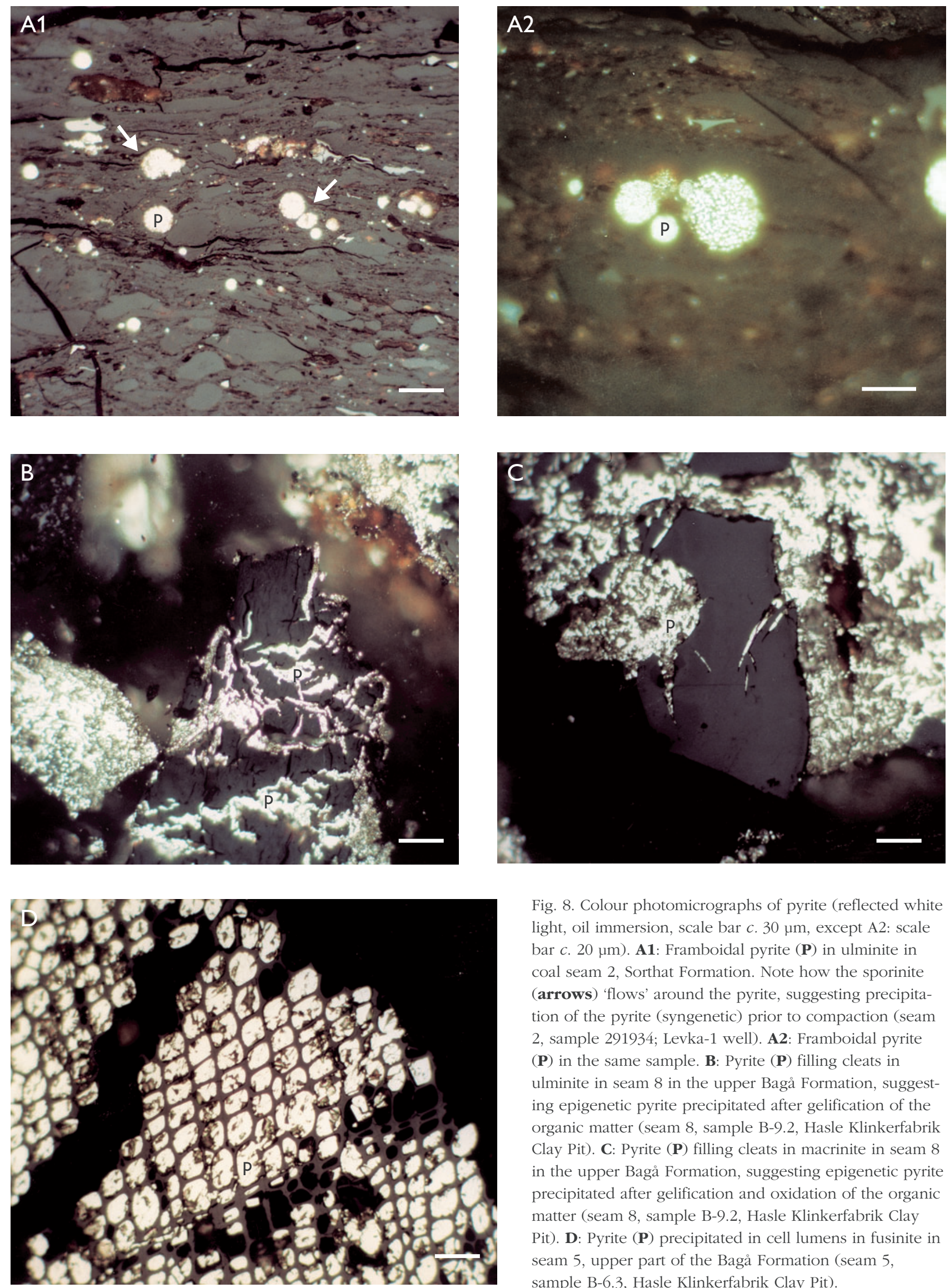

Fig. 8. Colour photomicrographs of pyrite (reflected white light, oil immersion, scale bar c. $30 \mu \mathrm{m}$, except A2: scale bar c. $20 \mu \mathrm{m})$. A1: Framboidal pyrite $(\mathbf{P})$ in ulminite in coal seam 2, Sorthat Formation. Note how the sporinite (arrows) 'flows' around the pyrite, suggesting precipitation of the pyrite (syngenetic) prior to compaction (seam 2, sample 291934; Levka-1 well). A2: Framboidal pyrite $(\mathbf{P})$ in the same sample. B: Pyrite (P) filling cleats in ulminite in seam 8 in the upper Bagå Formation, suggesting epigenetic pyrite precipitated after gelification of the organic matter (seam 8, sample B-9.2, Hasle Klinkerfabrik Clay Pit). C: Pyrite (P) filling cleats in macrinite in seam 8 in the upper Bagå Formation, suggesting epigenetic pyrite precipitated after gelification and oxidation of the organic matter (seam 8, sample B-9.2, Hasle Klinkerfabrik Clay Pit). D: Pyrite (P) precipitated in cell lumens in fusinite in seam 5, upper part of the Bagå Formation (seam 5 , sample B-6.3, Hasle Klinkerfabrik Clay Pit). 
ticles below $1 \mu \mathrm{m}$ and organically bound elements are not detected. The CCSEM analysis indicates that the inorganic fraction is dominated by $45 \mathrm{wt} \%$ quartz with subordinate pyrite and minor proportions of gypsum and clay minerals (Fig. 6). In general, the quartz is in the size range of clay and silt with the major part being fine-grained silt (4-16 $\mu \mathrm{m})$. The pyrite crystals are mainly within the size limits of silt followed by very fine-grained and fine-grained sand. Framboidal aggregates may account for the larger particles.

The peats accumulated mainly in anoxic and fully water-saturated freshwater mires as indicated by the very high content of humified organic matter in all of the seams in the Levka-1 section (high Gelification Index values, GI = huminite/inertinite, Fig. 7; Petersen \& Nielsen 1995). The high content of humocollinite and the abundance of hopanoids in the coals indicate pronounced bacterial activity reflecting abundance of nutrients and a relatively high $\mathrm{pH}$ level (Teichmüller 1989; Waples \& Machihara 1991; Peters \& Moldowan 1993). The significant amounts of pyrite in seams 2 and 4 and minor amounts in several other seams suggest occasional brackish - marine influence on the mires (Cohen et al. 1984; Phillips \& Bustin 1996a). The pyrite occurs in association with fusinite and inertinite, and as framboidal aggregates and minute crystals in huminite (Fig. 8A). It is interpreted to be mainly syngenetic. However, some of the pyrite, e.g. in seam 4, occurs infilling cleats in huminite and macrinite, thus suggesting that precipitation of pyrite also took place after gelification. The very small grain size of the mineral matter (clay to fine-grained silt) suggests that the mineral matter was deposited from suspension or may have been windborne.

Three coal seams, seams 3, 4 and 5, from the Korsodde succession have been investigated in detail (Fig. 5; Petersen \& Nielsen 1995). Seam 4 is petrographically very similar to the seams from the Levka-1 well and represents a wet, anoxic, and probably rheotrophic, nutrient-rich peat-forming environment. The seam overlies sediments from a shallow, vegetated coastal lake, that occasionally was flooded by the sea. Seam 3 also overlies coastal lake deposits, and the high mineral content in the seam reflects the development of the lake into a frequently inundated open mire. A peat mire failed to develop although rootlets indicate that in situ plants contributed to peat accumulation. Seam 5 overlies a lagoonal unit and constitutes the final, regressive phase in the evolution of an estuarine complex. The precursor peat was subjected to desiccation, possibly linked to a decreased rate of watertable rise.
Palynological evidence of the peat-forming vegetation

Palynological analyses were carried out on five coal samples from seams 2 and 15 in Levka- 1 and three samples from the sediment immediately below the coal seams. Although the parent plant affinities of palynomorphs from the Jurassic are uncertain in most cases, it has been possible to discriminate several groups of plants: ferns (pteridophytes) of the order Filicales (Class: Filicopsida), cycadophytes of the order Cycadales (Class: Gymnospermopsida), coniferophytes of the order Coniferales (Class: Gymnospermopsida), mosses (Division: Bryophyta), and microplankton-like acritarchs, marine green-algae (Tasmanites spp.) and a freshwater greenalgae (Botryococcus spp.; Table 1).

The palynomorph assemblage of the sediment sample below seam 2 in the Levka- 1 well is dominated by cycadalean pollen (c. 25\%, Chasmatosporites hians, C. minor, C. apertus) and Jurassic species of the family Pinaceae (c. 50\%, mainly Cerebropollenites thiergartii) (Table 1). The content of ferns is likewise pronounced (18\%). Moving up to the two coal samples, several pollen types that have affinities with conifers disappear, while Chasmatosporites bians, whose affinity lies with the order Cycadales (van Konijnenburg-van Cittert 1971), and Cerebropollenites thiergartii, whose affinity lies with the family Pinaceae, increase significantly in number upwards in the seam (Cycadales and Pinaceae pollen increases to $14 \%$ and $19 \%$ in the uppermost sample, respectively). However, the pollen Corollina torosus, the affinity of which is considered to lie with the large conifer Cheirolepidaceae (Srivastava 1976) and which constituted an important part of the Jurassic coniferous forests (Stewart 1983), appears in the lower coal sample. The occurrence of these larger gymnospermous plants is in agreement with the considerable content of the maceral subgroup humotelinite in the lower coal sample. The diversity of spores whose affinities lie with the ferns, in particular the family Osmundaceae, increases from the underlying sediment up into the coal. In the lower coal sample, the proportion of ferns reaches $56 \%$, suggesting a mire with a pronounced herbaceous vegetation. The generally high content of degraded organic matter (humodetrinite) in both coal samples correlates with a high proportion of these small plants. Spores related to mosses constitute a significant proportion of the coal assemblages. The palynomorph diversity is lower in the uppermost coal sample, possibly due to the influence of marine water as interpreted from the coal petrology and the occur- 
Table 1. Peat-forming plants based on palynological evidence

\begin{tabular}{|c|c|c|c|c|c|c|c|c|c|c|c|c|}
\hline \multirow{3}{*}{ Locality } & \multirow{3}{*}{ Seam } & \multirow{3}{*}{ Sample } & \multirow{3}{*}{$\begin{array}{l}\text { Sample } \\
\text { type }\end{array}$} & \multirow{3}{*}{$\begin{array}{c}\text { Filicopsida } \\
\%\end{array}$} & \multirow{3}{*}{$\begin{array}{c}\text { Lycopsida } \\
\%\end{array}$} & \multicolumn{4}{|c|}{ Gymnosperms \% } & \multirow{3}{*}{$\begin{array}{l}\text { Micro- } \\
\text { plankton } \\
\%\end{array}$} & \multirow{3}{*}{$\underset{\%}{\text { Bryophyta }}$} & \multirow{3}{*}{$\mathrm{n}^{\star}$} \\
\hline & & & & & & \multirow[t]{2}{*}{ Cycadales } & \multicolumn{3}{|c|}{ Coniferales } & & & \\
\hline & & & & & & & $\mathrm{P}^{*}$ & $\mathrm{~T}^{\dagger}$ & $\mathrm{G}^{\ddagger}$ & & & \\
\hline Øresund-13 & $\stackrel{1}{2 \mathrm{~cm} \text { below seam } 1}$ & $\begin{array}{c}6368 \\
247948\end{array}$ & $\begin{array}{c}\text { coal } \\
\text { black clay }\end{array}$ & $\begin{array}{l}64.3 \\
14.0\end{array}$ & $\begin{array}{l}5.1 \\
4.2\end{array}$ & $\begin{array}{r}3.5 \\
13.5\end{array}$ & $\begin{array}{l}11.2 \\
19.2\end{array}$ & $\begin{array}{l}0.5 \\
8.2\end{array}$ & $\begin{array}{l}15.4 \\
37.9\end{array}$ & $\begin{array}{l}0 \\
3.0\end{array}$ & $\begin{array}{l}0 \\
0\end{array}$ & $\begin{array}{l}196 \\
209\end{array}$ \\
\hline \multirow[t]{2}{*}{ Øresund-18 } & $\begin{array}{c}4 \mathrm{~cm} \text { above seam } 1 \\
1 \\
1 \\
1 \\
1 \\
2 \mathrm{~cm} \text { below seam } 1 \\
4 \mathrm{~cm} \text { below seam } 1\end{array}$ & $\begin{array}{c}247943 \\
6371 \\
6373 \\
6372 \\
6369 \\
247944 \\
247945\end{array}$ & $\begin{array}{l}\text { clay/silt } \\
\text { coal } \\
\text { coal } \\
\text { coal } \\
\text { coal } \\
\text { light clay } \\
\text { light clay }\end{array}$ & $\begin{array}{c}5.1 \\
16.0 \\
23.7 \\
41.7 \\
0 \\
73.9 \\
71.4\end{array}$ & $\begin{array}{l}6.2 \\
2.5 \\
1.7 \\
0 \\
0 \\
0 \\
0\end{array}$ & $\begin{array}{c}1.1 \\
7.3 \\
5.1 \\
16.7 \\
0 \\
4.3 \\
4.4\end{array}$ & $\begin{array}{c}10.7 \\
14.1 \\
8.5 \\
0 \\
40.0 \\
0 \\
1.1\end{array}$ & $\begin{array}{c}14.1 \\
25.6 \\
30.5 \\
8.3 \\
0 \\
0 \\
3.3\end{array}$ & $\begin{array}{r}58.2 \\
33.5 \\
23.7 \\
16.6 \\
40.0 \\
5.9 \\
11.0\end{array}$ & $\begin{array}{c}4.6 \\
0.5 \\
1.7 \\
12.5 \\
0 \\
14.4 \\
4.4\end{array}$ & \begin{tabular}{r}
\multicolumn{1}{c}{0} \\
0.5 \\
5.1 \\
4.2 \\
20.0 \\
1.5 \\
4.4
\end{tabular} & $\begin{array}{r}178 \\
206 \\
59 \\
24 \\
5 \\
69 \\
91\end{array}$ \\
\hline & $\begin{array}{c}2 \\
2 \\
2 \mathrm{~cm} \text { below seam } 2\end{array}$ & $\begin{array}{c}6375 \\
6374 \\
247947\end{array}$ & $\begin{array}{c}\text { coal } \\
\text { coal } \\
\text { dark clay }\end{array}$ & $\begin{array}{l}61.4 \\
46.0 \\
20.3\end{array}$ & $\begin{array}{l}2.6 \\
9.8 \\
8.8\end{array}$ & $\begin{array}{r}1.3 \\
2.0 \\
14.7\end{array}$ & $\begin{array}{r}18.6 \\
6.9 \\
10.4\end{array}$ & $\begin{array}{l}1.3 \\
2.0 \\
4.7\end{array}$ & $\begin{array}{l}14.8 \\
32.3 \\
36.0\end{array}$ & $\begin{array}{l}0 \\
1.0 \\
5.1\end{array}$ & $\begin{array}{l}0 \\
0 \\
0\end{array}$ & $\begin{array}{r}75 \\
102 \\
193\end{array}$ \\
\hline \multirow[t]{2}{*}{ Levka-1 } & $\begin{array}{c}2 \\
2 \\
3 \mathrm{~cm} \text { below seam } 2\end{array}$ & $\begin{array}{l}291934 \\
291932 \\
247938\end{array}$ & $\begin{array}{c}\text { coal } \\
\text { coal } \\
\text { coaly clay }\end{array}$ & $\begin{array}{l}10.8 \\
56.1 \\
18.0\end{array}$ & $\begin{array}{l}0 \\
0 \\
0\end{array}$ & $\begin{array}{r}13.5 \\
8.4 \\
24.6\end{array}$ & $\begin{array}{r}18.9 \\
6.3 \\
50.2\end{array}$ & $\begin{array}{l}0 \\
6.3 \\
0.6\end{array}$ & $\begin{array}{r}32.5 \\
12.5 \\
6.6\end{array}$ & $\begin{array}{l}5.4 \\
0 \\
0\end{array}$ & $\begin{array}{c}18.9 \\
10.4 \\
0\end{array}$ & $\begin{array}{r}37 \\
48 \\
167\end{array}$ \\
\hline & $\begin{array}{c}15 \\
15 \\
15 \\
2 \mathrm{~cm} \text { below seam } 15 \\
3 \mathrm{~cm} \text { below seam } 15\end{array}$ & $\begin{array}{c}6386 \\
6383 \\
6379 \\
247940 \\
247941\end{array}$ & $\begin{array}{l}\text { coal } \\
\text { coal } \\
\text { coal } \\
\text { clay } \\
\text { clay }\end{array}$ & $\begin{array}{l}33.3 \\
24.5 \\
28.9 \\
43.5 \\
43.4\end{array}$ & $\begin{array}{l}0 \\
0 \\
0 \\
0 \\
0\end{array}$ & $\begin{array}{l}28.5 \\
40.0 \\
42.0 \\
11.9 \\
18.2\end{array}$ & $\begin{array}{r}12.4 \\
11.1 \\
8.1 \\
33.7 \\
31.5\end{array}$ & $\begin{array}{l}4.9 \\
3.3 \\
1.6 \\
2.0 \\
0.5\end{array}$ & $\begin{array}{r}19.7 \\
14.4 \\
11.3 \\
8.9 \\
6.4\end{array}$ & $\begin{array}{l}0 \\
0 \\
0 \\
0 \\
0\end{array}$ & $\begin{array}{l}1.2 \\
6.7 \\
8.1 \\
0 \\
0\end{array}$ & $\begin{array}{r}81 \\
90 \\
62 \\
202 \\
203\end{array}$ \\
\hline \multirow[t]{6}{*}{ Bagå Clay Pit } & 1 & B-1.1 & coal & 62.7 & 13.2 & 0 & 14.2 & 0 & 5.5 & 0 & 4.4 & 91 \\
\hline & 2 & B-2.1 & coal & 31.3 & 9.7 & 0 & 25.7 & 8.3 & 20.8 & 0 & 4.2 & 144 \\
\hline & $\begin{array}{l}3 \\
3\end{array}$ & $\begin{array}{l}\text { B-3.2 } \\
\text { B-3.1 }\end{array}$ & $\begin{array}{l}\text { coal } \\
\text { coal }\end{array}$ & $\begin{array}{l}50.9 \\
54.1\end{array}$ & $\begin{array}{l}10.5 \\
16.2\end{array}$ & $\begin{array}{l}0 \\
0\end{array}$ & $\begin{array}{r}12.3 \\
2.7\end{array}$ & $\begin{array}{l}0 \\
2.7\end{array}$ & $\begin{array}{l}24.6 \\
21.6\end{array}$ & $\begin{array}{l}0 \\
2.7\end{array}$ & $\begin{array}{l}1.7 \\
0\end{array}$ & $\begin{array}{l}57 \\
37\end{array}$ \\
\hline & 4 & B-4.1 & coal & 53.3 & 22.3 & 0 & 22.2 & 0 & 2.2 & 0 & 0 & 45 \\
\hline & 5 & B-6.9 & coal & 24.7 & 31.1 & 0 & 24.6 & 0 & 19.6 & 0 & 0 & 61 \\
\hline & $\begin{array}{c}6 \\
\text { few } \mathrm{cm} \text { below } 6\end{array}$ & $\begin{array}{l}\text { B-7.2 } \\
\text { B-7.1 }\end{array}$ & $\begin{array}{c}\text { coal } \\
\text { black clay }\end{array}$ & $\begin{array}{l}30.7 \\
36.2\end{array}$ & $\begin{array}{r}3.6 \\
21.3\end{array}$ & $\begin{array}{l}0 \\
0\end{array}$ & $\begin{array}{l}19.8 \\
27.5\end{array}$ & $\begin{array}{l}0 \\
0\end{array}$ & $\begin{array}{l}45.9 \\
12.5\end{array}$ & $\begin{array}{l}0 \\
0\end{array}$ & $\begin{array}{l}0 \\
2.5\end{array}$ & $\begin{array}{r}111 \\
80\end{array}$ \\
\hline
\end{tabular}

$\begin{array}{lll}* \text { Pinaceae. } & \ddagger \text { Other gymnospermous pollen. } & \pi \text { Three dinoflagellates. } \\ \dagger \text { Taxodiaceae. } & \S \text { Mainly acritarchs, some Tasmanites and Botryococcus. } & \star \text { Number of palynomorphs counted. }\end{array}$

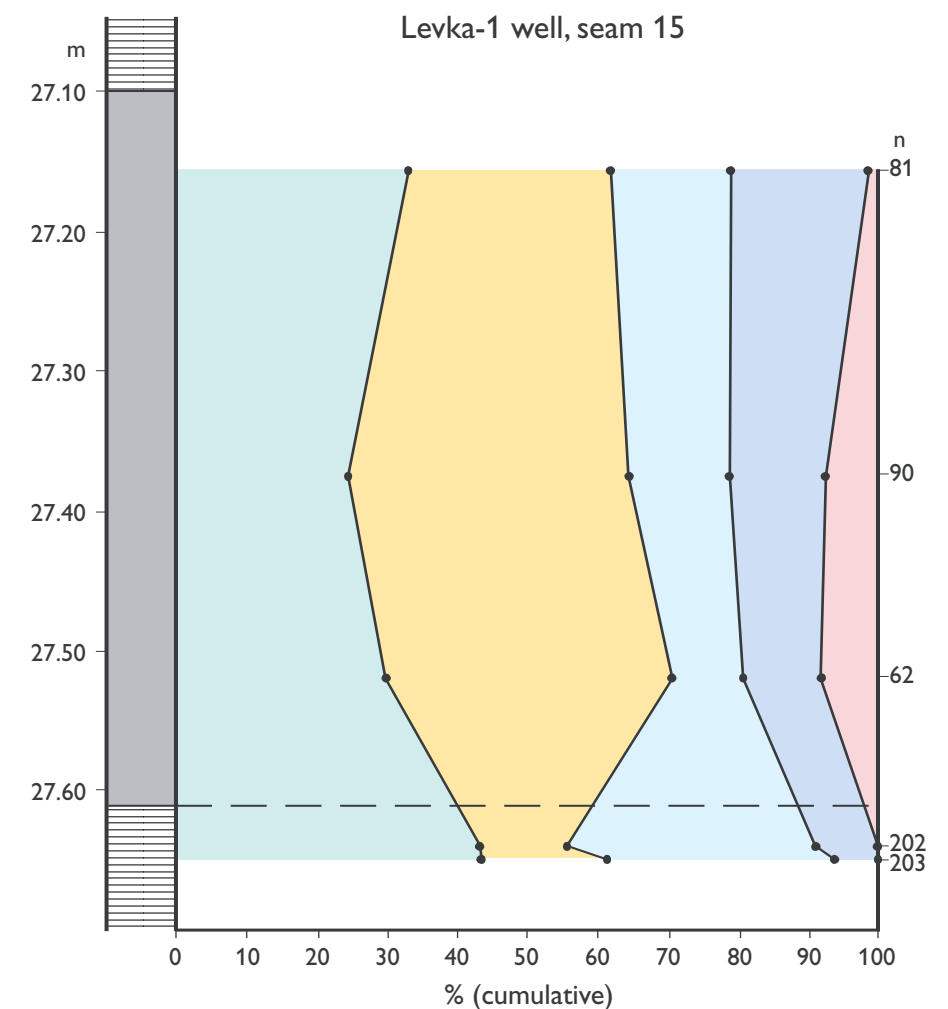

640
Interpreted plant groups

$\square$ Ferns (Filicopsida)

Cycadophytes (Cycadales)

Coniferophytes (Coniferales)

Gymnosperms, other

Mosses (Bryophyta)

Lithology

$\square$ Coal

Eudstone

Fig. 9. The succession of main plant groups in seam 15 , Levka-1 well, as suggested by the botanical affinities of palynomorphs and their abundance in percentages. n, number of palynomorphs counted. 
rence of a probable acritarch species (Lecaniella foveata; Batten et al. 1994; Petersen \& Nielsen 1995).

The clay samples taken immediately below seam 15 in the Levka-1 well contain a significant content of the same pollen species identified in seam 2 whose affinities lie with the order Cycadales and Jurassic species of the family Pinaceae (Fig. 9; Table 1). Fern spores are present below seam 15 in considerable amounts (43\%, mainly Deltoidospora spp.), and the diversity of spores related to ferns is greater than in the sediment sample below seam 2. The most pronounced changes in the palynomorph assemblages in seam 15 compared to the underlying sediment are a significant decrease in the proportion of pollen whose affinities are with the family Pinaceae, a decrease in the amount of fern spores, and a considerable increase in the proportion of pollen whose affinities are with the cycadophytes (Fig. 9; Table 1). Despite differences in types and amounts of the recorded pollen species among the three coal samples in seam 15 , they display a rather uniform composition. The coal petrographic composition is also uniform, conforming with studies on recent peat deposits, which have shown a correlation between peat vegetation and peat composition (Cohen \& Spackman 1977; Phillips \& Bustin 1996b). Thus, the mire vegetation may have been dominated by gymnospermous plants and a secondary proportion of ferns characterised by the genera Dicksonia or Coniopteris and the family Osmundaceae (Tralau 1968; van Konijnenburg-van Cittert 1978). This might correlate with the dominance of humotelinite over humodetrinite in the seam. The lowermost coal sample has both the smallest amount of gymnospermous pollen and the lowest proportion of humotelinite of the three coal samples. In general, the palynomorph assemblages suggest that the peat-forming vegetation of seam 15 was of higher diversity than that of seam 2 , which may be explained by the influence of saline water in the precursor mire of seam 2 .

\section{Duration of peat formation}

The compaction ratio for peat to bituminous coal varies between 4.1:1 and 30:1 (Ryer \& Langer 1980). A peat:coal compaction ratio of 10:1 may be assumed for the subbituminous coals in this study (see also McCabe 1991). The tropical Batang Hari River peat deposit in Sumatra has an accumulation rate of $c .1 .8 \mathrm{~mm} / \mathrm{yr}$, whereas the cold temperate peat deposit in Maine has been accumulating at a rate of c. $0.6 \mathrm{~mm} / \mathrm{yr}$ (Cameron et al. 1989). An average accumulation rate of $1 \mathrm{~mm} / \mathrm{yr}$ may thus be a reasonable assumption for the warm temperate to subtropical Jurassic climate. Using this assumption, the Late Pliensbachian - Early Toarcian peat-forming mires on Bornholm existed between 800 and 5700 years, with an average of $c .2300$ years.

\section{Other Lower Jurassic coal-bearing strata in the Fennoscandian Border Zone}

Hettangian-Sinemurian mires are represented by coal and coaly mudstones within the Munkerup Member and the Sose Bugt Member of the Arnager-Sose Fault Block on the south coast of Bornholm (Figs 2, 3). The poorly exposed Munkerup Member consists primarily of lake deposits (Gry 1969; Gravesen et al. 1982; Koppelhus 1991). Periodically, the lacustrine environment developed into mires. Increasing deoxygenation of the lakes and encroachment of vegetation is evident

\section{Rønne Formation}

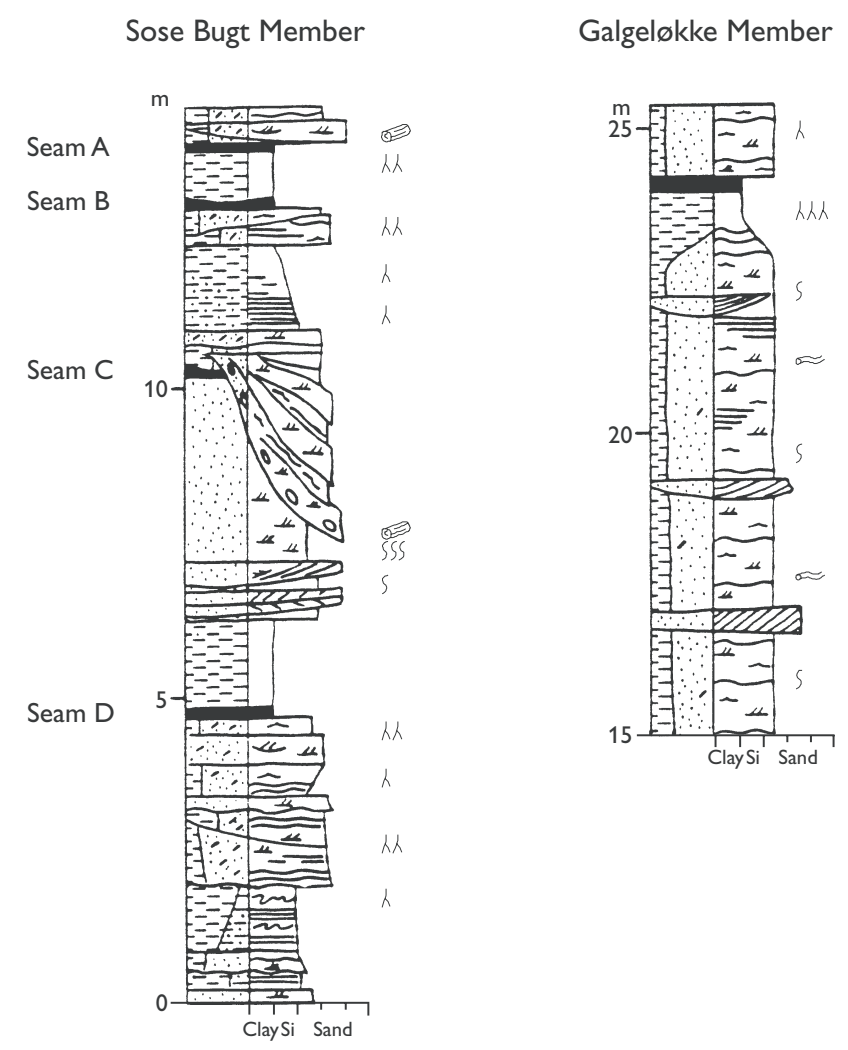

Fig. 10. Sedimentological log of the coastal Sose Bugt succession (Hettangian-Sinemurian Sose Bugt Member) and Galgeløkke cliff section (Sinemurian Galgeløkke Member). After Gravesen et al. (1982); section heights refer to the original sections of Gravesen et al. (1982). For legend, see Fig. 4. 

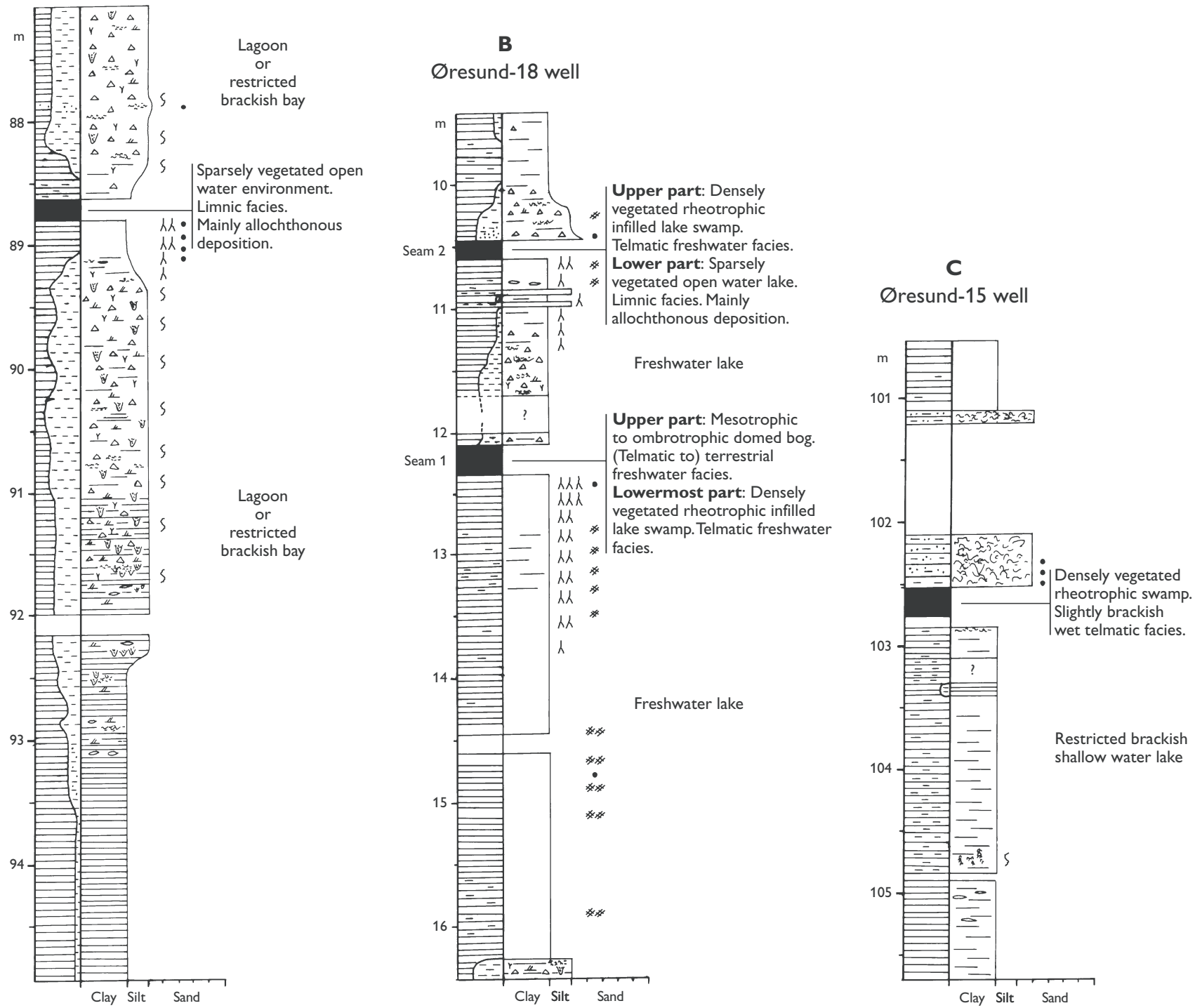

Fig. 11. A: Sedimentological core-log of the studied Hettangian-Sinemurian part of the Øresund-13 well. B: Sedimentological core-log of the studied Hettangian-Sinemurian part of the Øresund-18 well. C: Sedimentological core-log of the studied Sinemurian part of the Øresund-15 well. Modified after Petersen (1994); reference level: metres below sea level. For legend, see Fig. 4.

from the gradual transition from clayey, rooted sediments to the overlying coaly mudstones. The coaly mudstones are inertinite-rich, contain pyrite, and are to a large extent allochthonous, reflecting deposition in freshwater to brackish, open water environments (Petersen 1993). The Sose Bugt Member consists of lacustrine, fluvial, lagoonal, and restricted marine shoreface to offshore sediments (Figs 2, 3, 10; Surlyk et al. 1995). The occurrence of marine palynomorphs at certain levels within the terrestrial part of the succession indicates occasional marine incursions. The four $0.12-0.30 \mathrm{~m}$ thick, mainly allochthonous, mineral-rich coaly mudstones were deposited in shallow lakes on a coastal plain
(Petersen 1993; Surlyk et al. 1995). The mires developed largely under freshwater conditions, but may have periodically been influenced by marine water.

In the neighbouring Rønne-Hasle Fault Block, the Rønne Formation is dominated by lagoonal units with coal seams deposited in an overall coastal plain environment (Nielsen 1995). The exposed section of the Sinemurian Galgeløkke Member consists of sandy and muddy lagoonal, tidal flat and tidal channel complex deposits (Figs 3, 10; Sellwood 1972; Gravesen et al. 1982). An inertinite-rich coal seam, $0.10-0.35 \mathrm{~m}$ thick, overlies wavy- and flaser-bedded tidal flat heteroliths. The seam represents a dominantly freshwater peat bog 
with a domed surface (Fig. 7, GI values < 1), implying a significant change from the tidal flat environment that prevailed prior to peat formation (Petersen 1993), and the possible presence of a diastem below the coal seam. Siliciclastic deposition may have occurred contemporaneously nearby, but the elevated peat surface hindered flooding of the peat deposit (e.g. Staub \& Esterle 1994; Phillips \& Bustin 1996b). The high content of well-preserved pyrofusinite, which represents fossil charcoal (Scott 1989), indicates that wildfires occurred in the bog. This resulted in a high inertinite content in the seam as shown by low GI values in the TPI versus GI diagram (Fig. 7). The coal seam contains small amounts of pyrite towards the top, which probably was precipitated due to migration of sulphate ions into the peat from the overlying brackish sediments after peat formation was terminated.

Similar paralic depositional environments existed in the Øresund area in Hettangian-Sinemurian times (Fig. 1). The bioturbated heteroliths underlying a $0.18 \mathrm{~m}$ thick, inertinite- and mineral-rich coal seam in the Øresund-13 well represent deposition in a shallow, restricted bay or lagoon (Fig. 11A ; Petersen 1994). After the shallow area was filled, it became vegetated and accumulation of mainly allochthonous organic matter resistant to degradation during transportation took place in an open freshwater mire. Both seams $1(0.25 \mathrm{~m})$ and $2(0.15 \mathrm{~m})$ in the Øresund-18 well overlie lake fill sediments (Fig. 11B; Petersen 1994). The presence of rooted claystones below the seams demonstrates that the gradual fill of the lakes promoted plant growth. Both seams represent rheotrophic, probably nutrient-rich freshwater mires, although the precursor peat of seam 1 may temporarily have evolved to a more domed state.

Sinemurian coal-bearing strata occur in the Øresund-15 well, and the claystones underlying the coal seam were deposited in a shallow, weakly brackish lake situated in a coastal plain (Fig. 11C). The preserved stratification and absence of trace fossils suggest a poorly oxygenated sediment. The $0.16 \mathrm{~m}$ thick, huminite-dominated coal seam represents an occasionally slightly brackish, nutrient-rich swamp established on top of the lake-fill.

A c. $3 \mathrm{~cm}$ thick coaly mudstone occurs in the uppermost Lower Jurassic in the Skagen-2 well in north Jylland (referred to as the Fjerritslev Formation by Michelsen 1978). The coaly mudstone represents an allochthonous deposit, which is emphasised by the high content of the mineral-rich microlithotype carbominerite ( 71 vol.\%), microlaminated detrital macerals, and macerals resistant to degradation during transportation (inertinite: 39 vol.\%; liptinite: 9 vol.\%). Oxidised cutinites may reflect oxidation of the organic matter during transportation. The occurrence of pyrite (2 vol.\%) suggests that the open water environment was brackish or periodically influenced by marine water. The peat mire was situated in a coastal environment, consistent with the position of the bed within a thin unit that correlates with transgressive marine mudstones further to the west (i.e. basinwards; Nielsen 1995).

\section{Palynological evidence of the peat-forming vegetation in the Øresund area}

A total of twelve samples were analysed from the Øresund-13 and -18 wells; these comprise seven coal samples, four samples from the sediment immediately below the coal seams, and one sample immediately above a seam. In addition to the plant groups mentioned from the Sorthat Formation coals, club mosses (Class: Lycopsida) were identified in these coals (Table 1).

A sample was taken from the coal seam in the Øresund-13 well and from the black clay about $2 \mathrm{~cm}$ below the seam. The latter shows a higher diversity than the coal sample. Acritarchs (Lecaniella foveata, Leiosphaeridia spp. and a possible Cymatiosphaera spp.), Tasmanites spp. and a possible dinoflagellate cyst (? Mancodinium semitabulatum) occur only in the sediment sample. This is consistent with the interpretation of the sedimentary environment as a lagoon or brackish restricted bay and the seam as a freshwater deposit (Petersen 1994). Spores related to ferns, in particular Deltoidospora spp., whose affinities lie with the two fern genera Coniopteris or Dicksonia (Tralau 1968), are common in the clay. However, coniferalean and cycadalean pollen are more abundant. Bisaccate species and a pollen of unknown affinity are also abundant. In combination, the pollen related to gymnosperms constitute $78 \%$ of the palynomorph assemblage in the clay sample (Table 1).

In contrast, in the coal sample the proportion of gymnosperm pollen is only $31 \%$. In particular, the proportions of the species Chasmatosporites hians and Perinopollenites elatoides, whose affinities are with the Cycadales and the coniferophyte family Taxodiaceae (Guy-Ohlsson 1986) respectively, are significantly lower. However, spores whose affinities lie with the order Lycopodiales, the fern genera Dicksonia and the fern family Osmundaceae (van Konijnenburg-van Cittert 1978) are more abundant. In total, the proportion of fernrelated spores increases to approximately $64 \%$ in the coal sample. Thus, the palynomorphs indicate a change 


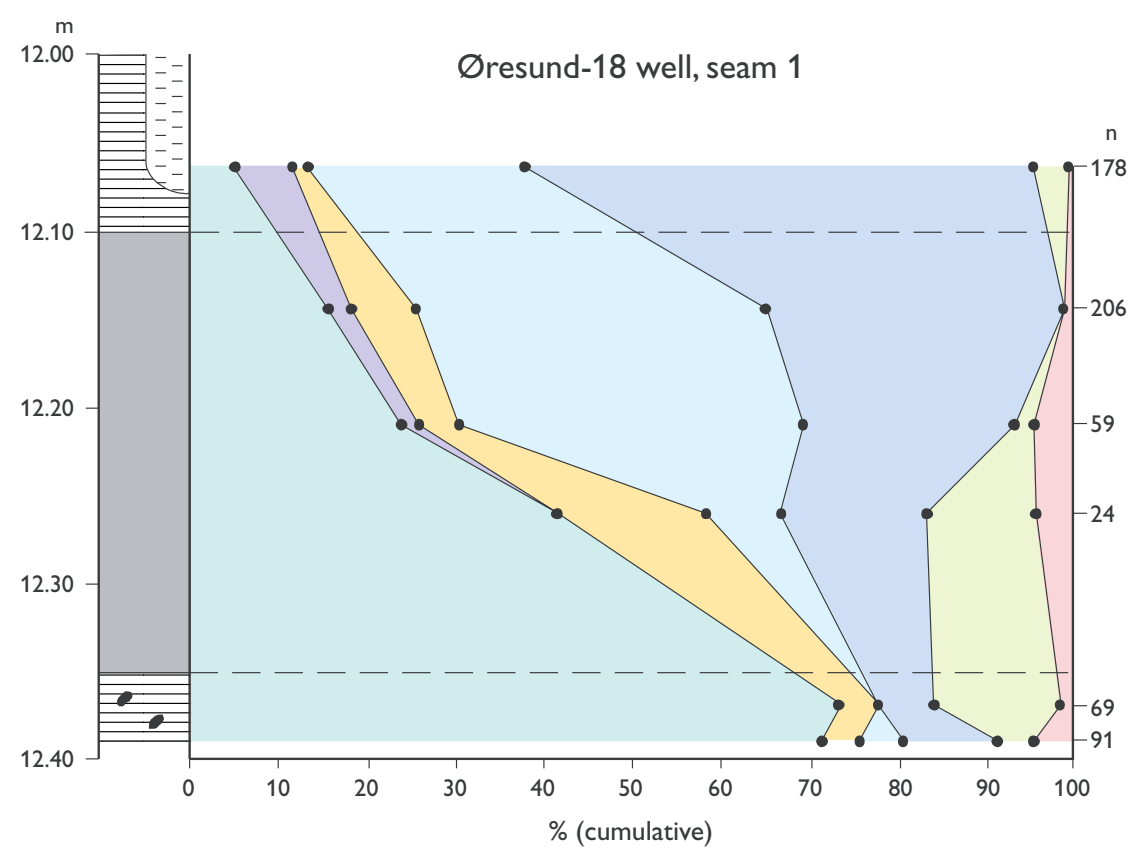

Interpreted plant groups

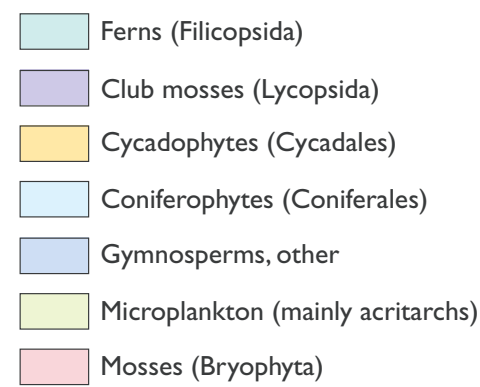

Lithology

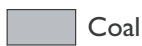

Mudstone

$\overline{-z_{-}-}$Siltstone

- Carbonaceous detritus

Fig. 12. The succession of main plant groups in seam 1, Øresund-18 well, as suggested by the botanical affinities of palynomorphs and their abundance in percentages. $\mathbf{n}$, number of palynomorphs counted.

in the composition of the vegetation from the siliciclastic environment to the mire environment. The sparse mire vegetation probably consisted to a large extent of herbaceous plants.

The sediment samples below seam 1 in the $\varnothing$ resund-18 well are dominated by fern spores (71-74\%, mainly Deltoidospora spp.) and up to $15 \%$ acritarchs (Fig. 12; Table 1). Upwards through the coal seam, spores related to ferns decrease and constitute only $16 \%$ in the uppermost sample. Club mosses (Retitriletes clavatoides) were probably present in the late peat stages corresponding to slightly wetter conditions. Most notable compared to the underlying clay is the significant content of taxodiaceous pollen (Perinopollenites elatoides) and bisaccate pollen related to unknown gymnosperm plants. Pollen and spores also show that plants belonging to the Cycadales (Chasmatosporites hians, C. apertus), the Pinaceae (Pinuspollenites minimus, Cerebropollenites macroverrucosus, C. thiergartii), and the Bryophyta constituted parts of the original mire vegetation (Fig. 12; Table 1). An evolutionary link between the parent plant of C. macroverrucosus and the extant Tsuga has recently been suggested, although the parent plant of the former probably became extinct during the Cretaceous (Batten \& Dutta 1997). Acritarchs and dinoflagellates are present. The composition of the vegetation cannot be directly correlated to the maceral composition of the seam, which may be due to the high proportion of oxidised organic matter (inertinite), particularly inertodetrinite. The occurrence of club mosses in the upper part of the seam may correspond to a return to more wet and nutrient-rich conditions, which would be consistent with the increased content of mineral matter. In contrast, the occurrence of microplankton in the seam is of particular interest. No indications of saline water influence, such as pyrite, have been observed in the seam, and the sediments have been interpreted as freshwater deposits (Petersen 1994). However, the occurrence of acritarchs suggests, at least temporarily, brackish conditions. On the basis of the palynomorph assemblage, the mire may have been covered with a dominantly gymnospermous vegetation and a significant, subordinate proportion of ferns and club mosses.

Spores (mainly Deltoidospora spp.) probably derived from ferns increase from c. 20\% in the dark clay immediately below seam 2 in the Øresund- 18 well to $61 \%$ in the upper part of the seam, whereas the proportions of cycadalean pollen and pollen with unknown gymnosperm affinities decrease significantly upwards (Table 1). The contribution of the Taxodiaceae family was much less important in the precursor mire of seam 2 than in that of seam 1. The mire may have been characterised by a prominent herbaceous vegetation, and the highest proportion of spores derived from club mosses occurs in the lower part of the seam representing wet, 
open-water conditions. The contribution of plant tissue from ferns together with club mosses in the precursor mire is compatible with the high content of detrital organic matter (humodetrinite) in the coal.

\section{Duration of peat formation}

The coaly mudstones from the Sose Bugt Member are very low in rank (Petersen et al. 2003, this volume), and a compaction ratio of $4: 1$ for peat:lignite (Esterle \& Ferm 1994) may provide a better estimate than that adopted for the sub-bituminous coals (see above). Using this value and ignoring the relatively high content of mineral matter, the original carbonaceous deposits were between 0.5 and $1.2 \mathrm{~m}$ thick, and organic matter accumulation lasted for about 500-1200 years. The Hettangian Munkerup Member is located in the same fault block as the Hettangian-Sinemurian Sose Bugt Member. The boundary between the two members is not exposed (Gry 1969; Gravesen et al. 1982), but the thickness of the sediment package between the seams of the two members is insignificant with regard to coalification. Thus, although the Munkerup Member coals yield higher reflectance values than the Sose Bugt Member seams (Petersen et al. 2003 , this volume), the $4: 1$ compaction ratio is also applied to the Munkerup Member coals. Using this compaction ratio, the original peat deposits of the Munkerup Member were also between 0.5 and $1.2 \mathrm{~m}$ thick, and peat accumulation lasted for about 500-1200 years. The original peat deposit represented by the coal seam in the Galgeløkke coastal cliff section in the Rønne Graben had a maximum thickness of $3.5 \mathrm{~m}$ (peat:coal compaction ratio: 10:1), corresponding to 3500 years of peat accumulation. On average, the mires represented by the investigated seams in the Rønne Formation thus existed for $c .1200$ years.

Assuming a 10:1 compaction ratio for the Lower Jurassic coal seams in the Øresund area, the original peat thickness was $1.5-2.5 \mathrm{~m}$ and the duration of peat accumulation was $1500-2500$ years. On average, the peat mires existed for 1850 years.

\section{Middle Jurassic coal-bearing strata}

\section{Bagå Formation, Bornholm}

The lower to middle part of the Baga Formation in the Hasle Klinkerfabrik Clay Pit is a heterogeneous, clayrich succession about $60 \mathrm{~m}$ thick that is characterised by stacked units (c. $10 \mathrm{~m}$ thick) of laminated, grey dark grey clay with silt and sand laminae and subordinate beds of cross-bedded or laminated sandstones, often showing rootlets (Koppelhus \& Nielsen 1994). These units are separated by coaly mudstones or coal seams, associated with rooted horizons that record the periodic establishment of peat-forming mires. Fossil plant fragments, small logs, stems, and leaves are common in the clay. The palynomorph assemblages are all non-marine and dominated by pteridophyte spores and gymnosperm pollen (Hoelstad 1985; Koppelhus \& Nielsen 1994), and the total sulphur content in the coaly mudstones and coal seams is generally less than 0.80 $\mathrm{wt} \%$, indicating a freshwater environment (Casagrande 1987). Thus, the clay was deposited in freshwater lakes, which were gradually filled and transformed into openwater or peat-forming freshwater mires. The sand beds represent crevasse splays and channel deposits. The upper part of the Bagå Formation becomes more sandy, with some very poorly sorted sand beds, occasionally with large kaolinised granite boulders deposited by debris flows that originated from the granite horst located immediately to the east (Gry 1969; Gravesen et al. 1982; Nielsen 1995). Pyrite nodules are common in the sand beds. Based on the clastic facies and the proximity to the major graben fault against the granitic basement, a small alluvial fan environment with deposition from sheet wash and mud flows is envisaged.

\section{Coal seam composition and peat-forming environments}

Eight coal seams, 0.05-1.90 m thick, have been investigated in the upper part of the Bagå Formation (seams $1-8$ of Petersen 1993). The seams are petrographically complex, with varying amounts of inertinite (1-72 vol.\%; $74 \%$ of the studied coal samples contain 20-60 vol.\%) and huminite (16-89 vol.\%; 71\% of the studied samples contain more than $30 \mathrm{vol} . \%)$, and often a considerable content of minerals (2-57 vol.\%; $57 \%$ of the studied samples contain 10-20 vol.\%; Petersen 1993). Fusinite is a prominent component of the inertinite maceral group (up to $41 \mathrm{vol} . \%$ ). Pyrite occurs in seven of the eight seams. Framboidal pyrite has not been observed, although in several of the seams significant amounts of pyrite (up to 36 vol.\%) fill cell-lumens of fusinite, occur as massive pyrite or fill cleats in gelified organic matter (Fig. 8B, C, D; Petersen 1993).

Analysis of a sample from seam 5 by CCSEM shows that the inorganic fraction is dominated by pyrite ( $46 \mathrm{wt} \%$ ), 


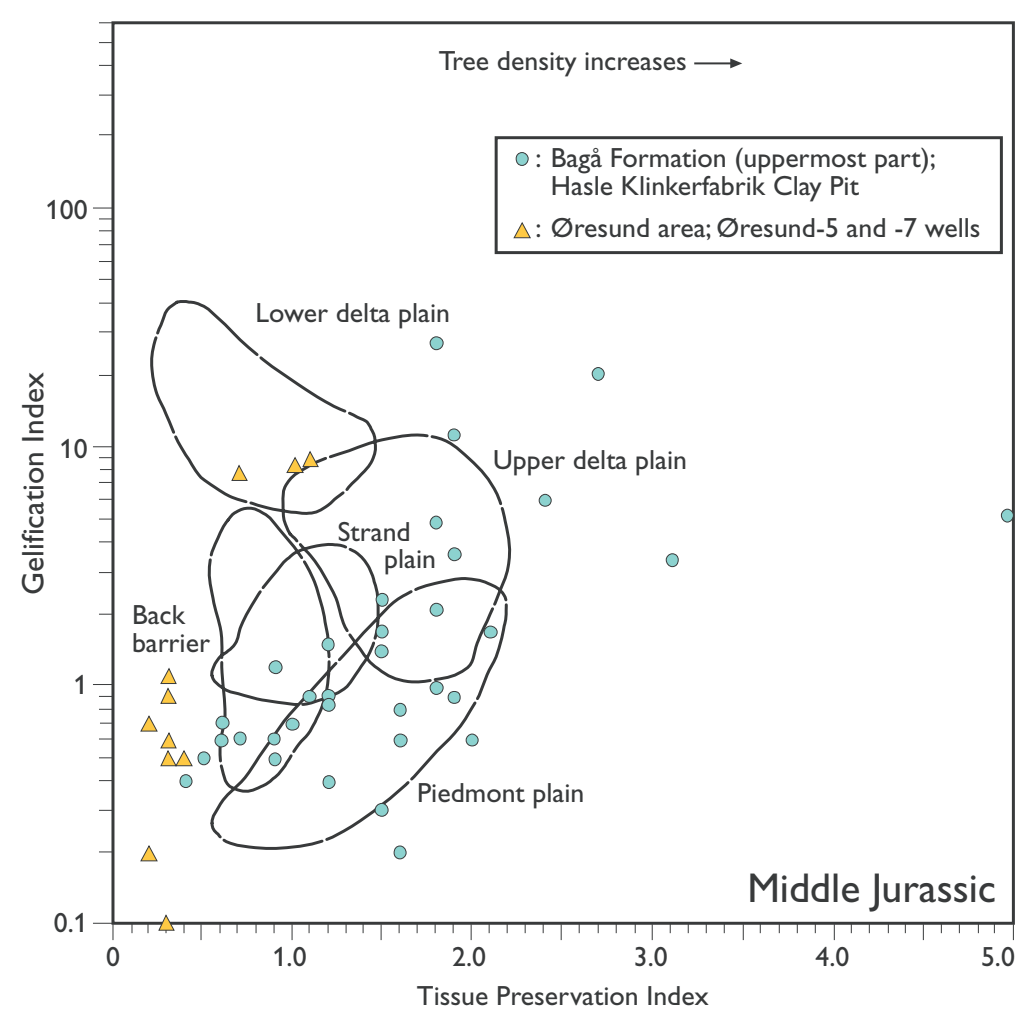

Fig. 13. Coal samples from the Middle Jurassic on Bornholm and the Øresund area plotted on the TPI vs. GI diagram (Fig. 7). Most of the samples from the upper Bagå Formation plot within the field of the piedmont plain. followed by quartz (19 wt $\%$ ), clay associated with pyrite (13 wt\%) and kaolinite (10 wt\%; Fig. 6). The majority of the quartz is in the grain-size range of silt (in particular coarse silt, 32-64 $\mu \mathrm{m}$ ), to fine-grained sand, whereas most of the pyrite is of fine-grained sand grade.

The eight coal seams from the upper part of the Bagå Formation were formed in freshwater swamps, that occasionally were established on the alluvial plain. The occurrence of several well-defined root horizons below a thick coal seam (seam 5 of Petersen 1993) indicates repeated episodes of siliciclastic deposition followed by colonisation of the sediments by plants. A level coloured by humus substances below each root horizon was possibly formed by a low-standing watertable, which together with the petrography of seam 5 imply an unstable watertable. Most of the samples from seam 5 plot in the field of the piedmont plain in the TPI versus GI diagram (Fig. 13), consistent with the alluvial fan interpretation. Varying amounts of detrital minerals in the seams is attributed to periodic outwash from the nearby granitic horst. In addition to pyrite and clay associated with pyrite, the inorganic fraction in the $125-135 \mathrm{~cm}$ interval in seam 5 is characterised by quartz, primarily of coarse silt to fine-grained sand size, and kaolinite. The comparatively high content of kaolinite is probably related to the proximity of the mires to the weathered granitic basement of the Bornholm High to the east. A large proportion of impure coals and an abundance of inertinite-rich lithotypes occur in piedmont coal seams in the Springhill coalfield of Nova Scotia, where peatlands were nourished by groundwater discharge from alluvial fans and basin-margin fault-fed springs (Calder 1993, 1994). A similar small-scale scenario is envisaged for the sand-dominated, upper part of the Bagå Formation. Formation of dull coals due to severe oxidation in the piedmont plain setting has also been noted by Diessel (1986), and most of the upper Bagå Formation coals contain much inertinite. The inertinite may have formed due to a fluctuating watertable in the precursor mires, an inertinite-forming process known from recent peat-forming environments (Cohen \& Stack 1996; Moore et al. 1996). Fluctuations were probably related to seasonality as indicated by the occurrence of annual rings in wood from the coal seams in the Baga Formation (Höhne 1933). A peat-forming flora dominated by cellulose-rich plants (shrubs, herbs) is suggested by the maceral composition.

\section{Palynological evidence for the peat-forming vegetation}

Seven coal samples and one clay sample were analysed from coal seams 1-6 (Petersen 1993) in the upper part of the Bagå Formation. It is possible to discriminate several plant groups: ferns (Order: Filicales; Class: 
Filicopsida), club mosses (Class: Lycopsida), coniferophytes (Order: Coniferales; Class: Gymnospermopsida) and mosses (Division: Bryophyta; Table 1). Pollen related to cycadophytes were not found, although Höhne (1933) identified cycadophytes in the coals.

A sample from the lowermost part of seam 1 is characterised by a high diversity of spores, which are related to ferns of the family Osmundaceae and the genera Dicksonia or Coniopteris (Tralau 1968; van Konijnenburgvan Cittert 1978), to the orders Lycopodiales and Selaginellales, and to bryophytes. Fern-related spores constitute $63 \%$ and club mosses $13 \%$ of the assemblage (Table 1). Pollen whose affinities lie with the Cheirolepidaceae and Pinaceae are also present. Compared to seam 1 , seam 2 is characterised by a higher diversity and a larger proportion of pollen whose affinities are with the families Pinaceae, Taxodiaceae, and other gymnosperms (Table 1). The spore assemblage has a different composition from that of seam 1 and makes up a smaller proportion of the total palynomorphs. It implies, however, a rather similar overall composition of the herbaceous vegetation. Based on coal petrography, Petersen (1993) suggested that the vegetation in the mires represented by seams 1 and 2 was generally small-sized and consisted of abundant herbaceous plants, small trees, shrubs and tree ferns. Palynological evidence of tree ferns has not been found in the coals, and the abundance of spores whose affinities are with herbaceous plants indicates that ferns and club mosses were more common in these mires than deduced from the maceral composition, which has a rather high content of humotelinite.

The rest of the samples from seams 3-6 are rather similar. The diversity of spores related to ferns is considerably lower than in seams 1 and 2; however, they still constitute up to $54 \%$ of the assemblages (Table 1). Ferns in particular seem to have been abundant in the mires represented by seams 3 and 4 . The most abundant is Deltoidospora spp., whose affinity is with the genera Dicksonia or Coniopteris (Tralau 1968). The proportion of club mosses was significant in the mires, and the spores (mainly Retitriletes austroclavatoides, $R$. clavatoides, R. semimuris, Sestrosporites pseudoalveolatus) amount to $22 \%$ and $31 \%$ in seams 4 and 5 , respectively. These spores are particularly associated with mineral-rich levels in the coals implying that the plants favoured wetter and more nutrient-rich conditions. The pollen species Cerebropollenites macroverrucosus which is related to the gymnosperm genus Tsuga of the family Pinaceae (Tralau 1968; Batten \& Dutta, 1997), is abundant. In the coal sample from seam 6 , the pollen
Vitreisporites pallidus is abundant. The affinity of this pollen is with the Caytoniales (van Konijnenburg-van Cittert 1971), a gymnosperm order of uncertain relationship (Stewart 1983).

A peat-forming vegetation consisting of abundant herbaceous and shrubby plants and some larger trees was suggested by Petersen (1993). To some extent this is supported by the palynomorph assemblages, but the proportion of gymnospermous trees may have been greater than deduced from the maceral composition. Plants belonging to the family Pinaceae were present. Reconstruction of the gymnospermous vegetation in the mires is difficult due to the high proportion of pollen of unknown affinity (Table 1).

\section{Duration of peat formation}

Assuming a peat accumulation rate of $1 \mathrm{~mm} / \mathrm{yr}$ and a peat:coal compaction ratio of 10:1 (see above), the original peat deposits represented by the coal seams in the upper part of the Bagå Formation were between 0.5 and $19.0 \mathrm{~m}$ thick, and peat accumulation occurred in the mires for between 500 and 19000 years.

\section{Other Middle Jurassic coal-bearing strata in the Fennoscandian Border Zone}

Several seams, $0.16-0.70 \mathrm{~m}$ thick, are present in the Øresund-5 and -7 wells, overlying parallel-laminated to homogeneous claystones deposited in freshwater lakes (Figs 14, 15; Petersen 1994). The abundance of coalified plant remains and the upwards-increasing content of organic matter, coal particles, coal streaks and rootlets in the claystones towards the coal seams record the gradual fill of the lakes and deterioration of the oxygen supply in the mires. The lower part of the Øresund- 5 seam represents a drier mire environment, whereas the upper part of the seam is a carbonaceous claystone deposited in an open freshwater environment. This indicates that the rising groundwater level gradually outpaced organic matter accumulation, and peat formation was terminated by lacustrine flooding. Seams 1, 3 and 4 in the Øresund7 well contain a higher inertinite content as shown by low GI values (Fig. 13), and they represent bogs that were probably subjected to a fluctuating watertable (Petersen 1994). The mire represented by seam 2 was also established after a lake had been filled with sediment. However, the mire was continuously water-saturated and anoxic, and probably nutrient-rich and rheotrophic. 


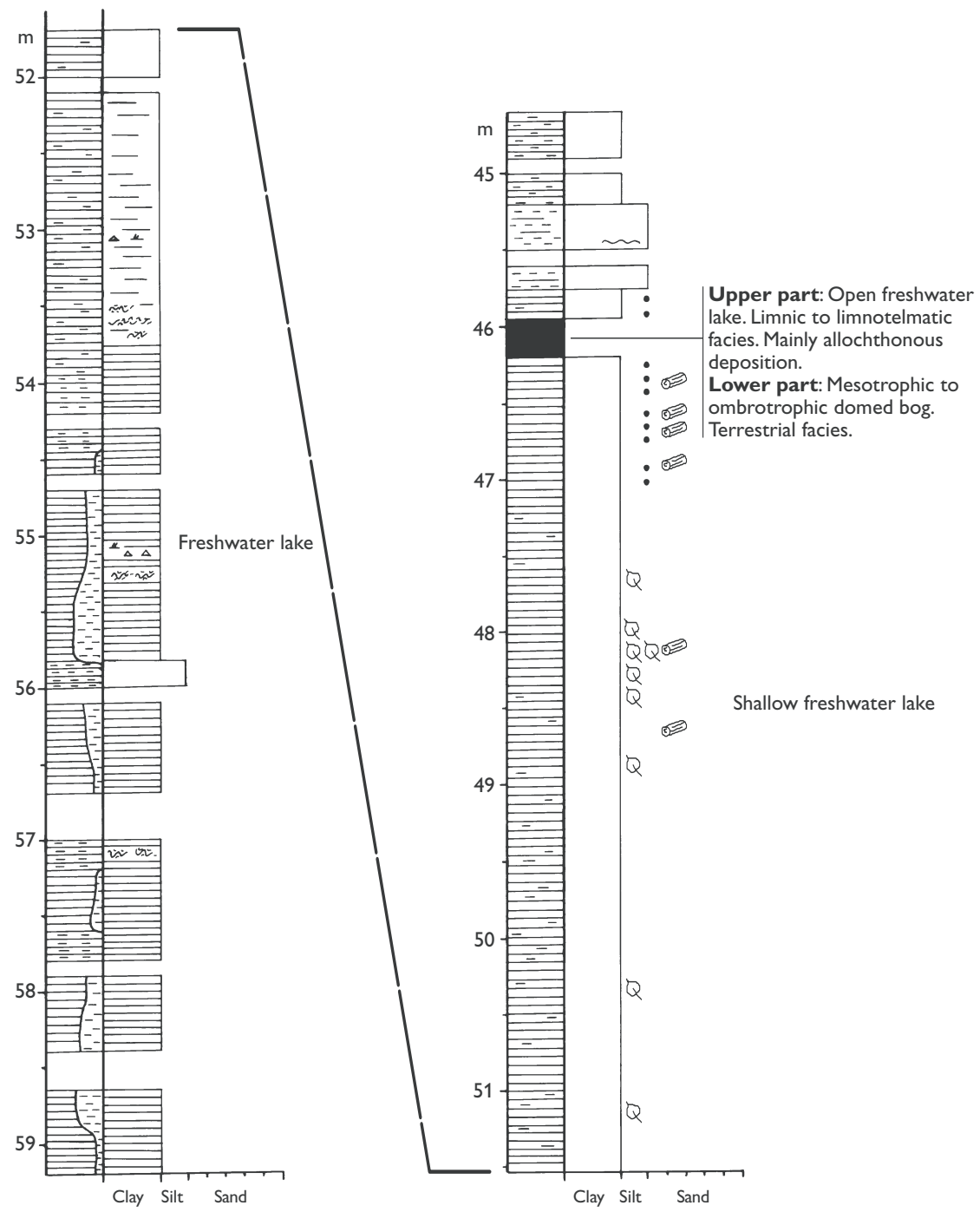

Fig. 14. Sedimentological core-log of the Jurassic succession of the Øresund-5 well. Modified after Petersen (1994); reference level: metres below sea level. For legend, see Fig. 4.
The Middle Jurassic peat-forming freshwater mires in the Øresund area were thus located in an overall lakedominated wetland with a prolific flora indicated not only by the coal seams but also by the abundance of coalified leaves and branches in the claystones. There is no evidence of marine influence, and the continental sedimentation kept pace with the subsidence-induced base-level rise.

In north Jylland, thin coal seams and carbonaceous mudstones are present in the Middle Jurassic Haldager Sand Formation. Analysis of a $4 \mathrm{~cm}$ thick seam in the Frederikshavn-3 well shows that it is inertinite- and mineral-rich ( $75 \mathrm{vol} . \%$ and $17 \mathrm{vol} . \%$, respectively), which may indicate an allochthonous origin. However, black carbonaceous clay and rootlets below the seam indicate a gradual change to oxygen deficient, low energy conditions and the establishment of vegetation. Degraded liptinite components suggest fungal and/or bacterial attack under well-oxidised conditions. This and the scarcity of huminite ( 1 vol.\%) may imply that the seam was severely oxidised, possibly due to a fall in the watertable following the accumulation of the organic matter. Minerals are easily incorporated into a thin layer of organic matter, and the carbonaceous seam is probably autochthonous and was deposited in a shallow, slightly brackish area, as suggested by the presence of pyrite ( 4 vol.\%). The seam is overlain by coaly matter associated with quartz grains, and poorly sorted darkbrown clay and sand, indicating a gradually rising watertable.

\section{Duration of peat formation}

The original peat deposits in the Øresund area were between 1.6 and $7.0 \mathrm{~m}$ thick and the peat-forming environments existed for between 1600 and 7000 years using the assumptions discussed above. Although some 


\section{Øresund-7 well}

Fig. 15. Sedimentological core-log of the Jurassic succession of the Øresund-7 well. Modified after Petersen (1994); reference level: metres below sea level. For legend, see Fig. 4.

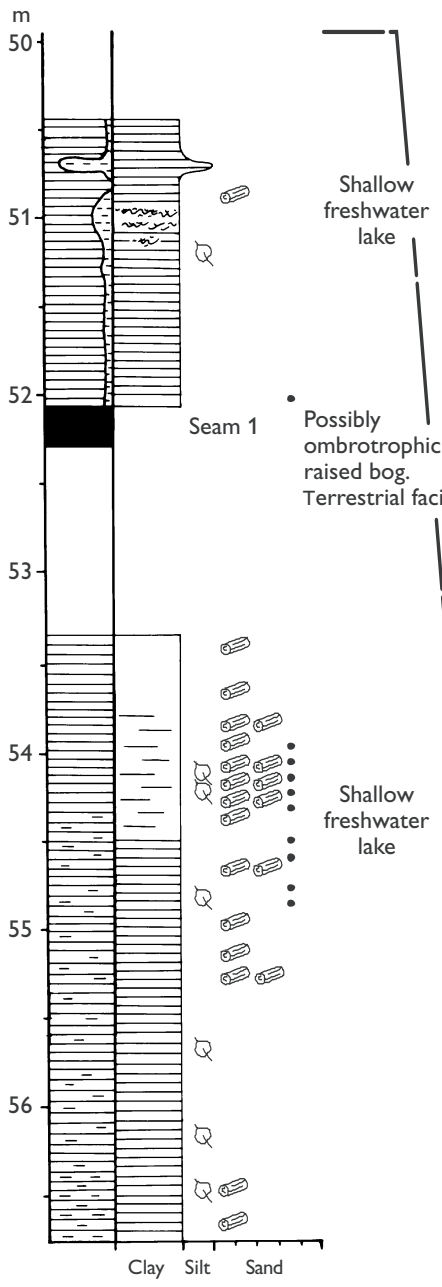

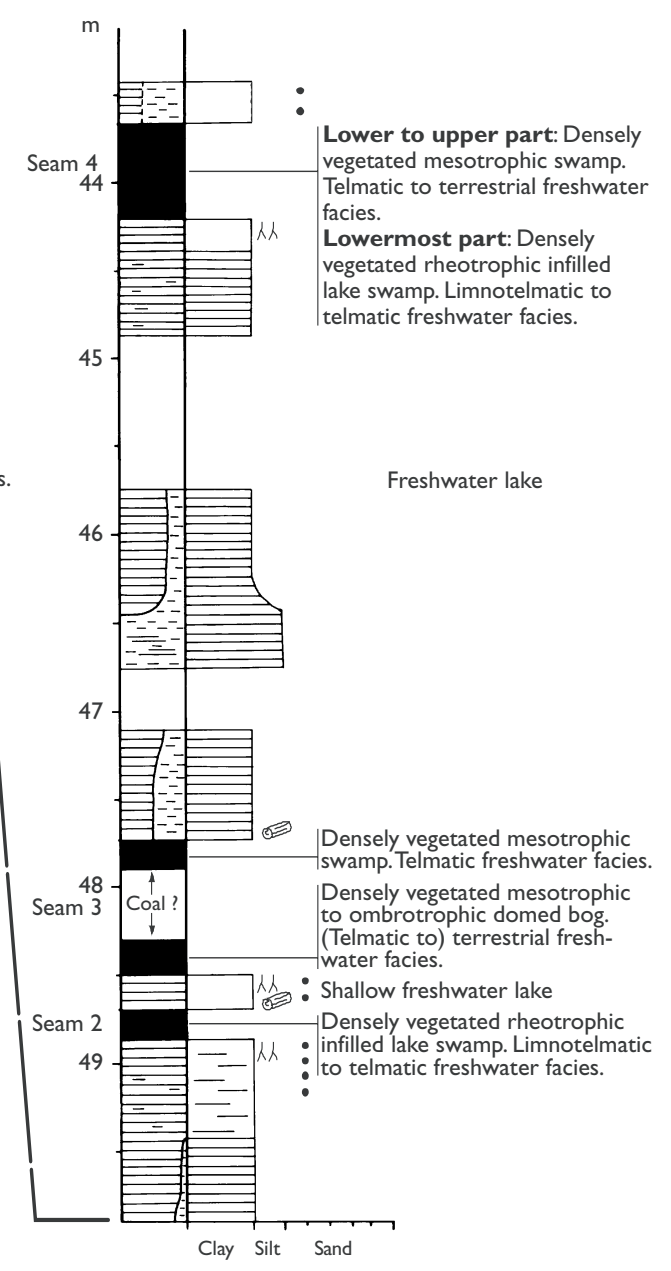

of the mires were rather short-lived, the data demonstrate that certain of the Middle Jurassic peat mires in the Øresund area were able to exist for longer periods than the Early Jurassic mires in the same area.

\section{Discussion}

\section{Factors controlling peat formation}

Peat formation occurred in the Fennoscandian Border Zone from north Jylland, through Øresund and Skåne to Bornholm during Early-Middle Jurassic times. The conditions for peat accumulation were most favourable to the south-east as indicated by an increase in number and thickness of the seams from north Jylland to Bornholm.

The Upper Pliensbachian - Lower Toarcian Sorthat Formation coals differ from the Bathonian upper Bagå Formation coals in terms of composition, thickness and palynological content. The Lower Jurassic coal seams represent peat accumulation in low-lying interchannel and abandoned channel mires on a lower coastal plain in an overall transgressive setting (Petersen \& Nielsen 1995). In paralic settings, rising relative sea-level causes a rise in the groundwater table and a more landwards ponding of coarse sediments, which may result in the formation of extensive peatlands (Diessel 1994; Petersen \& Andsbjerg 1996; Petersen et al. 1998). Peat accumulation in the Sorthat precursor mires was favoured by a continuously high-standing watertable and anoxic conditions, and only small amounts of very fine-grained detrital mineral particles reached the mires. The mires were probably rheotrophic and periodically saline-water influenced, and the resulting coals are generally very huminite-rich. The limited thickness of the seams (up to $0.57 \mathrm{~m}$, but generally between $0.08 \mathrm{~m}$ and $0.26 \mathrm{~m}$ ) reflects a rather short duration of peat accumulation (average for all seams of 2300 years), determined by a fairly rapid relative sea-level rise. The sea-level rise was governed by an overall eustatic rise (Hallam 1988; Haq et al. 1988) and a subsidence rate of $c .30 \mathrm{~m} / \mathrm{my}$ (Petersen 
\& Nielsen 1995). Most of the coal seams represent the boundary between two succeeding lake/lagoonal successions, i.e. they were deposited during the transition from a period of relatively slow rise in the watertable to a period during which the watertable rose more rapidly. Peat formation began when the lake/lagoon or abandoned channel was filled and turned into lowlying mires. Peat accumulation probably continued during the initial phase of the succeeding faster rise in watertable, as accumulation of organic matter may have been favoured by sediment starvation due to upstream ponding of clastic sediments. Peat formation was terminated by lacustrine or lagoonal flooding of the mires, when the watertable rise outpaced the rate of organic matter accumulation. Similarly, the formation and duration of the Hettangian-Sinemurian coastal mires in the Fennoscandian Border Zone was strongly controlled by a relative sea-level rise, and the peats obtained thicknesses of only $0.5-3.5 \mathrm{~m}$. On average, the investigated mires in the Rønne Formation existed for $c .1200$ years and the mires in the Øresund area for 1850 years.

The principal controlling factor on the development of the Early Jurassic mires in the Fennoscandian Border Zone was thus a general rise of the groundwater table that favoured the development of waterlogged, possibly rheotrophic and nutrient-rich mires, and hindered the development of domed bogs in most cases. This resulted in the dominance of huminite-rich coals and carbonaceous claystones. A similar mechanism has been presented for the Westphalian A in the Warrior Basin, Alabama, where domed peat formation may have been hindered due to extremely rapid basin subsidence in spite of a suitably warm and humid climate (Eble et al. 1994). Hunt (1989) suggested that eastern Australian Permian delta plain coals are consistently high-vitrinite coals, because the peats formed under high watertables principally controlled by a high subsidence rate.

During the Middle Jurassic, the subsidence rate was much lower as clearly shown by thinner Middle Jurassic sediment packages (up to $200 \mathrm{~m}$ in c. $21 \mathrm{Ma}$; Gradstein et al. 1994) in the Danish Basin and Fennoscandian Border Zone compared to those in the Lower Jurassic (up to $1000 \mathrm{~m}$ in c. $26 \mathrm{Ma}$ ). The marked change in subsidence rate and basin configuration was caused by uplift of the Ringkøbing-Fyn High and the Danish Basin south-west of the Sorgenfrei-Tornquist Zone (Nielsen 1995, 2003, this volume). These changes may have been related to thermal doming centrally in the North Sea area (Underhill \& Partington 1993) and to an important Middle Jurassic volcanic event in central Skåne that was possibly associated with, or preceded by, uplift in the form of a rift dome (F. Surlyk, personal communication 1997). The reduced subsidence rate coupled with a more stable eustatic sea level (Hallam 1988; Haq et al. 1988) resulted in a more inland position for the Middle Jurassic mires in the Fennoscandian Border Zone and on Bornholm than that for the Early Jurassic mires. The proximity of the Bathonian mires (upper Bagå Formation) on Bornholm to granitic basement is reflected in the coarser grain size of the quartz particles and a much higher kaolinite content than observed in the Sorthat Formation coals. The thickest of the upper Bagå Formation coal seams $(1.9 \mathrm{~m})$ corresponds to a precursor peat thickness of $19 \mathrm{~m}$ and an estimated 19000 years of peat accumulation. From the Øresund area, a maximum of 7000 years is estimated. This suggests that on occasion peat accumulation was able to keep pace with the increase in accommodation space for a relatively long period of time. At other times, the rate of peat accumulation may have outpaced the rate of watertable rise resulting in the development of domed peats. As noted above, this style of peat development probably resulted from the combination of a low subsidence rate and a stable eustatic sea level, which worked together to limit flooding controlled by relative sea-level rise.

The coal petrography indicates that most of the investigated Middle Jurassic mires were exposed to fluctuations in the groundwater table, probably controlled by a seasonal climate; such periodic falls in the watertable level favoured oxidation of the peat surfaces. In contrast, the seasonal climate probably had a more limited influence on the level of the watertable in the Early Jurassic coastal mires, where a high-standing watertable was governed by a more or less continuous rise of relative sea level. Oxidation of the organic matter on the Middle Jurassic peat surface implies that the estimates of peat accumulation periods may be a rough minimum. The combined effect of a seasonal climate and possibly peat accretion above the watertable level resulted in coal seams with a higher content of inertinite. A low subsidence rate has been similarly inferred to account for oxidation of the precursor peats of Permian high-inertinite coals in eastern Australia (Hunt 1989; Hunt \& Smyth 1989). The fluctuating watertable in the Middle Jurassic mires may have favoured wildfire frequency and the formation of fire-derived inertinite; however, the nature of the inertinite, particularly in the coals from the Øresund area, is indicative of derivation by oxidation. The presence of inertinitic maceral precursors formed by oxidation in recent peat deposits (Cohen \& Stack 1996; Moore et al. 1996), makes this suggestion likely. 


\section{The peat-forming vegetation based on palynological evidence}

The palynological evidence of the peat-forming vegetation suggests a Lower Jurassic flora with a prominent proportion of ferns together with cycadophytes, coniferophytes from the families Pinaceae and Taxodiaceae, unknown gymnospermous plants, and bryophytes. Although the overall composition of the plant communities seems to have been rather uniform, variations in the composition of the palynomorph assemblages (and coal composition) in the seams and between seams may reflect variations in the peat-forming plant communities. These variations are probably related to specific environmental conditions in the mires as demonstrated in recent peat systems (Cohen 1973; Esterle \& Ferm 1994; Phillips \& Bustin 1996b). The limited knowledge of the ecology and environmental tolerance of the plants restricts the understanding of the palaeoecological differences between the mire systems as indicated by various palynomorph assemblages. The Middle Jurassic seams from the upper Bagå Formation are characterised by the common occurrence of spores whose affinities lie with the order Lycopodiales and the absence of pollen related to the order Cycadales. Club mosses are particularly abundant in mineral-rich levels corresponding to wet, nutrient-rich conditions in the precursor mires, or common inundations. Bryophytes seem to have been present, together with ferns and coniferophytes. Of particular note is the absence of pollen related to Cycadales in the Middle Jurassic coals, particularly in view of their common occurrence in the Lower Jurassic samples. According to Lapo \& Drozdova (1989), cycadophytes are rarely found in Jurassic coals because they preferred drier habitats. However, Höhne (1933) noted the presence of cycadophytes in the Bagå Formation coals, although this may have been stratigraphically lower in the succession. It is notable that the genus Nilssonia, considered to represent the foliage of cycadophytes, occurs in Lower Jurassic claystones on Bornholm (Möller 1903). Hence the palynomorphs from the Lower Jurassic seams whose affinities are with the Cycadales could have originated from vegetation outside the mires.

In general, there is a relatively good correspondence between the interpretation of the peat-forming vegetation based on macerals and the palynological evidence of the peat-forming vegetation. In order to strengthen the interpretations based on macerals, however, it is necessary to acquire specific knowledge of the peat-forming plants, i.e. the stature, structure and the wood content of the tissues; furthermore, the degradational conditions should also be considered (Pierce et al. 1995). Biological aspects of the parent plants should be incorporated, if possible, in particular to account for the variation in spore/pollen production by different species, but also to account for spores and pollen that may have been transported into the mires from the hinterland. It is clear that multidisciplinary studies of coals integrating palaeobotanical data with petrographic results provide the most detailed picture of the mire floras (see discussion by Scott 1991; DiMichele \& Phillips 1994).

\section{Origin and environmental significance of pyrite in the coals of the Sorthat and Bagå Formations}

The framboidal pyrite in the Sorthat Formation coals is interpreted to be syngenetic. Framboidal pyrite is normally considered to indicate the influence of saline water during peat formation because organic sulphur inherited from the peat-forming flora only accounts for low contents of sulphur and pyrite in freshwater environments (Cohen et al. 1984; Casagrande 1987; Phillips \& Bustin 1996a). However, the nature of the pyrite in the Bagå Formation coals and the lack of other evidence for marine influence suggest that this pyrite is mainly epigenetic in origin. It is therefore necessary to identify an external source of sulphur to account for the high content of pyrite in fairly well-defined intervals in the coals and the abundant pyrite concretions in the sand beds. The coal-bearing strata are faulted against the graben bounding fault, and sulphate-enriched porewater expelled from deeper levels may have migrated up through the fault zone and into the highly permeable sand beds and coal seams. Sulphate-rich porewater is associated with anhydrite deposits, and Zechstein and Triassic deposits with anhydrite and a very low content of organic matter are present in the Rønne Graben. Sulphate-rich porewater is known from Triassic strata in the Danish Basin (Gustafson \& Anderson 1979; Laier 1982). The pyrite nodules in the sand beds in the Bagå beds are often associated with coal particles. This suggests that the reduction of the sulphate and the precipitation of pyrite occurred where the local environment was reducing due to enrichment in organic matter. In the coal seams, pyrite is often found associated with fusinite, suggesting that precipitation was favoured by the higher porosity of the fusinite compared to the huminite (Fig. 8D). An analogous situation has been described from Carboniferous coal seams in a non- 
marine succession from Nova Scotia, Canada, where epigenetic pyrite fills fusain lenses, fractures and cleats (Beaton et al. 1993). The Carboniferous coal measures are in fault contact with rocks containing gypsum, anhydrite, carbonates, halite and potash salts, which are interpreted to be the source of the sulphur.

\section{Conclusions}

The development of the Early-Middle Jurassic mires in the Fennoscandian Border Zone occurred in a humid, warm-temperate to subtropical, weakly seasonal climate. During the Early Jurassic, mires were established on coastal plains facing the open sea to the west. Peat formation was mainly controlled by an overall fairly rapid rise of relative sea level governed by the general eustatic rise and a relatively high subsidence rate causing repeated lacustrine or lagoonal flooding of the mires. The Early Jurassic mires were relatively short-lived, averaging 1200 years (Rønne Formation), 1850 years (Øresund area) and 2300 years (Sorthat Formation), because watertable rise outpaced the rate of peat accumulation. The Lower Jurassic coals and coaly mudstones in the Fennoscandian Border Zone and on Bornholm represent peat deposits that were between 0.5 and $5.7 \mathrm{~m}$ thick, but generally were less than $3 \mathrm{~m}$ thick.

The Upper Pliensbachian - Lower Toarcian Sorthat Formation coals originated in continuously waterlogged, anoxic mires, and the high-standing watertable and the periodic marine influence on the mires favoured the formation of huminite-rich coals and the precipitation of framboidal pyrite. In addition to pyrite, the mineral matter is dominated by clay and fine-grained silt-sized quartz.

Uplift of the Ringkøbing-Fyn High and the main part of the Danish Basin south of the Sorgenfrei-Tornquist Zone in Aalenian times changed the basin configuration and influenced the accumulation of peat. The uplift, which may have been related to the formation of a large thermal dome in the central North Sea, and possibly also in Skåne, caused a strongly reduced subsidence rate within the Fennoscandian Border Zone. The low subsidence rate coupled with a relative stable eustatic sea level, resulted in a general regression such that the Middle Jurassic mires developed farther inland than those of the Early Jurassic. The setting enabled peat accumulation in the Middle Jurassic mires to keep pace with and occasionally outpace the watertable rise. Thus, some of the Middle Jurassic peat mires existed for rel- atively long periods. It is inferred from coals in the $\varnothing$ resund area that peat accumulation occurred for up to 7000 years and upper Bagå Formation coals testify that at certain times during the Bathonian, peat accumulation may have occurred on Bornholm without significant interruption for up to 19000 years. The combination of an inland position of the Middle Jurassic mires, a seasonal climate, and periodic peat accretion above the groundwater level caused temporary oxidation of the peat surfaces and the formation of inertiniterich coals. Watertable fluctuations within the upper Bagå Formation mires on Bornholm may further have been promoted by the generally sandy substrate of the alluvial plain. The proximity of these mires to the granitic basement areas to the east on Bornholm is reflected by a larger grain size of quartz particles and a higher kaolinite content than observed in the Sorthat Formation coals. The pyrite in the upper Bagå Formation coals is interpreted to be mainly epigenetic in origin, precipitated out of sulphate-enriched porewater expelled from underlying Zechstein-Triassic strata.

Palynological data indicate variations in the peatforming plant communities between coal seams. Variations within individual seams also suggest subtle changes in the mire environment, probably mainly of hydrological character, reflecting the evolution of the mire. The Hettangian-Sinemurian mires represented by the seams in the Øresund-18 well were characterised by an abundance of ferns, cycadophytes and at certain levels significant proportions of coniferophytes of the family Taxodiaceae. Club mosses were also represented. The Late Pliensbachian - Early Toarcian mires (seams 2 and 15 in the Levka-1 well, Sorthat Formation) were also characterised by an abundance of ferns. In contrast to the Sinemurian mires in the Øresund area, however, cycadophytes were more abundant, while coniferophytes of the family Taxodiaceae were much less common and club mosses were probably absent. The Bathonian mires represented by the seams in the upper Bagå Formation differ in particular from the Early Jurassic mires by the complete absence of cycadophytes and the abundance of club mosses, and by the rare occurrence of coniferophytes of the family Taxodiaceae. Ferns were significant components of the mires, as were Jurassic species of Pinaceae. It is tempting to relate the difference in the plant communities of the mires represented by the Sorthat and Bagå Formation coal seams to the distinctly different depositional settings represented by these seams. The Early Jurassic mires were waterlogged, anoxic and periodically marine-influenced, whereas the Bathonian mires developed under fresh- 
water conditions and were situated inland, where in particular the seasonal climate was important in promoting a fluctuating watertable. In general, there appears to be a relationship between the petrographic composition of the coals and the composition of the peatforming vegetation, as deduced from palynological evidence. Thus, the overall coal seam composition was controlled not only by allogenic factors but also by differences in vegetational input from the various peat-forming plant communities, which may account for the more subtle petrographic variations in the coal seams.

\section{Acknowledgement}

The paper benefited significantly from constructive reviews by D.J. Batten and C.R. Fielding.

\section{References}

Ahlberg, A. \& Arndorff, L. 1994: Pedogenesis and sedimentology of alluvial Upper Triassic (Middle Rhaetian) strata of Bjuv Member (Höganäs Formation), NW Skåne, southern Sweden. In: Ahlberg, A.: Deposition and diagenesis of the RhaetianHettangian succession (Triassic-Jurassic) in southern Sweden, 53 pp. Unpublished Ph.D. thesis, Lund University, Sweden.

Ahlberg, A., Sivhed, U. \& Erlström, M. 2003: The Jurassic of Skåne, southern Sweden. In: Ineson, J.R. \& Surlyk, F. (eds): The Jurassic of Denmark and Greenland. Geological Survey of Denmark and Greenland Bulletin 1, 527-541 (this volume).

Arndorff, L. 1993: Lateral relations of deltaic paleosols from the Lower Jurassic Rønne Formation on the Island of Bornholm, Denmark. Palaeogeography, Palaeoclimatology, Palaeoecology 100, 235-250.

Batten, D.J. \& Dutta, R.J. 1997: Ultrastructure of exine of gymnospermous pollen grains from Jurassic and basal Cretaceous deposits in Northwest Europe and implications for botanical relationships. Review of Palaeobotany and Palynology 99, 25-54.

Batten, D.J., Koppelhus, E.B. \& Nielsen, L.H. 1994: Uppermost Triassic to Middle Jurassic palynofacies and palynomiscellanea in the Danish Basin and Fennoscandian Border Zone. Cahiers de Micropaléontologie 9, 21-45.

Beaton, A.P., Kalkreuth, W. \& MacNeil, D. 1993: The geology, petrology and geochemistry of coal seams from the St. Rose and Chimney Corner coalfields, Cape Breton, Nova Scotia, Canada. International Journal of Coal Geology 24, 47-73.

Bertelsen, F. 1978: The Upper Triassic - Lower Jurassic Vinding and Gassum Formations of the Norwegian-Danish Basin. Danmarks Geologiske Unders $\varnothing$ gelse Serie B 3, 26 pp.

Calder, J.H. 1993: The evolution of a groundwater-influenced (Westphalian B) peat-forming ecosystem in a piedmont setting: the no. 3 seam, Springhill coalfield, Cumberland Basin, Nova Scotia. In: Cobb, J.C. \& Cecil, C.B. (eds): Modern and ancient coal-forming environments. Geological Society of America Special Paper 286, 153-180.

Calder, J.H. 1994: The impact of climate change, tectonism and hydrology on the formation of Carboniferous tropical intermontane mires: the Springhill coalfield, Cumberland Basin, Nova Scotia. Palaeogeography, Palaeoclimatology, Palaeoecology 106, 323-351.

Calder, J.H. \& Gibling, M.R. 1994: The Euramerican Coal Province: controls on Late Paleozoic peat accumulation. Palaeogeography, Palaeoclimatology, Palaeoecology 106, 1-21.

Cameron, C.C., Esterle, J.S. \& Palmer, C.A. 1989: The geology, botany and chemistry of selected peat-forming environments from temperate and tropical latitudes. International Journal of Coal Geology 12, 105-156.

Casagrande, D.J. 1987: Sulphur in peat and coal. In: Scott, A.C. (ed.): Coal and coal-bearing strata: recent advances. Geological Society Special Publication (London) 32, 87-105.

Cohen, A.D. 1973: Petrology of some Holocene peat sediments from the Okefenokee swamp-marsh complex of southern Georgia. Geological Society of America Bulletin 84, 3867-3878.

Cohen, A.D. \& Spackman, W. 1977: Phytogenic organic sediments and sedimentary environments in the Everglades mangrove complex. Part II: The origin, description and classification of the peats of southern Florida. Palaeontographica B 162, 71-114.

Cohen, A.D. \& Stack, E.M. 1996: Some observations regarding the potential effects of doming of tropical peat deposits on the composition of coal beds. International Journal of Coal Geology 29, 39-65.

Cohen, A.D., Spackman, W. \& Dolsen, P. 1984: Occurrence and distribution of sulfur in peat-forming environments of southern Florida. International Journal of Coal Geology 4, 73-96.

Diessel, C.F.K. 1986: On the relationships between coal facies and depositional environments. In: Diessel, C.F.K. (convener): Advances in the study of the Sydney Basin: Proceedings of the Symposium (Newcastle) 20, 19-22.

Diessel, C.F.K. 1992: Coal-bearing depositional systems, 721 pp. Berlin Heidelberg: Springer-Verlag.

Diessel, C.F.K. 1994: Part B - The application of sequence stratigraphy to coal geology. In: Boyd, R. \& Diessel, C.F.K. (eds) Sequence stratigraphy and its application to coal geology, 28th Newcastle Symposium, 14-17 April 1994. Short course notes, 1-65.

DiMichele, W.A. \& Phillips, T.L. 1994: Paleobotanical and paleoecological constraints on models of peat formation in the Late Carboniferous of Euramerica. Palaeogeography, Palaeoclimatology, Palaeoecology 106, 39-90.

Eble, C.F., Gastaldo, R.A., Demko, T.M. \& Liu, Y. 1994: Coal compositional changes along a mire interior to mire margin transect in the Mary Lee coal bed, Warrior Basin, Alabama, USA. International Journal of Coal Geology 26, 43-62.

Esterle, J.S. \& Ferm, J.C. 1994: Spatial variability in modern tropical peat deposits from Sarawak, Malaysia and Sumatra, Indonesia: analogues for coal. International Journal of Coal Geology 26, 1-41.

EUGENO-S Working Group 1988: Crustal structure and tectonic evolution of the transition between the Baltic Shield and the North German Caledonides (the EUGENO-S Project). Tectonophysics 150, 253-348. 
Florin, R. 1958: On Jurassic taxads and conifers from north-western Europe and eastern Greenland. Acta Horti Bergiani 17, 257-387.

Gradstein, F.M., Agterberg, F.P., Ogg, J.G., Hardenbol, J., van Veen, P., Thierry, J. \& Huang, Z. 1994: Mesozoic time scale. Journal of Geophysical Research 99, 24 051-24 074.

Graff-Petersen, P. \& Bondam, J. 1963: Hasle Klinkerfabrik Clay Pit. International Clay Conference Field Trip C, 1-14.

Gravesen, P., Rolle, F. \& Surlyk, F. 1982: Lithostratigraphy and sedimentary evolution of the Triassic, Jurassic and Lower Cretaceous of Bornholm, Denmark. Danmarks Geologiske Undersøgelse Serie B 7, 51 pp.

Gry, H. 1969: Megaspores from the Jurassic of the island of Bornholm, Denmark. Meddelelser fra Dansk Geologisk Forening 19, 69-89.

Gustafson, G. \& Anderson, O. 1979: Geotermi i SV-Skåne. Uppborrning och provpumpning av Höllviksnäs 1. Unpublished report, VIAK $\mathrm{AB}$, Sweden.

Guy-Ohlson, D. 1986: Jurassic palynology of the Vilhelmsfält Bore No. 1, Scania, Sweden, Toarcian-Aalenian, 127 pp. Stockholm: Section of Palaeobotany, Swedish Museum of Natural History.

Hallam, A. 1984: Continental humid and arid zones during the Jurassic and Cretaceous. Palaeogeography, Palaeoclimatology, Palaeoecology 47, 195-223.

Hallam, A. 1985: A review of Mesozoic climates. Journal of the Geological Society (London) 142, 433-445.

Hallam, A. 1988: A reevaluation of Jurassic eustasy in the light of new data and the revised Exxon curve. In: Wilgus, C.K. et al. (eds): Sea-level changes - an integrated approach. Society of Economic Paleontologists and Mineralogists Special Publication 42, 261-273.

Hallam, A. 1992: Phanerozoic sea-level changes. Perspectives in paleobiology and earth history series, 266 pp. New York: Columbia University Press.

Hamilton, D.S. \& Tadros, N.Z. 1994: Utility of coal seams as genetic stratigraphic sequence boundaries in nonmarine basins: an example from the Gunnedah Basin, Australia. American Association of Petroleum Geologists Bulletin 78, 267-286.

Haq, B.U., Hardenbol, J. \& Vail, P.R. 1988: Mesozoic and Cenozoic chronostratigraphy and cycles of sea-level change. In: Wilgus, C.K. et al. (eds): Sea-level changes - an integrated approach. Society of Economic Paleontologists and Mineralogists Special Publication 42, 71-108.

Harris, T. 1937: The fossil flora of Scoresbysund, East Greenland, Part 5. Meddelelser om Grønland 112, 78-104.

Hoelstad, T. 1985: Palynology of the uppermost Lower to Middle Jurassic strata on Bornholm, Denmark. Bulletin of the Geological Society of Denmark 34, 111-132.

Höhne, R. 1933: Beiträge zur Stratigraphie, Tektonik und Paläogeographie des südbaltischen Rhät-Lias, insbesondere auf Bornholm. Abhandlungen aus dem geologisch-palaeontologischen Institut Greifswald, Heft 12, 31-70.

Hunt, J.W. 1989: Permian coals of eastern Australia: geological control of petrographic variation. International Journal of Coal Geology 12, 589-634.

Hunt, J.W. \& Smyth, M. 1989: Origin of inertinite-rich coals of Australian cratonic basins. International Journal of Coal Geology
11, 23-46.

Japsen, P. 1993: Influence of lithology and Neogene uplift on seismic velocities in Denmark: Implications for depth conversion of maps. American Association of Petroleum Geologists Bulletin 77, 194-211.

Kalkreuth, W. \& Leckie, D. 1989: Sedimentological and petrographical characteristics of Cretaceous strandplain coals: a model for coal accumulation from the North American Western Interior Seaway. International Journal of Coal Geology 12, 381-424

Koch, J.-O. 1983: Sedimentology of Middle and Upper Jurassic sandstone reservoirs of Denmark. Geologie en Mijnbouw 62 , 115-129.

Koppelhus, E.B. 1991: Palynology of the Lower Jurassic Rønne Formation on Bornholm, eastern Denmark. Bulletin of the Geological Society of Denmark 39, 91-109.

Koppelhus, E.B. \& Nielsen, L.H. 1994: Palynostratigraphy and palaeoenvironments of the Lower to Middle Jurassic Bagå Formation of Bornholm, Denmark. Palynology 18, 139-194.

Laier, T. 1982: Fluid analysis and scaling investigations of the Skagerrak transitional formation water of Thisted-2. Unpublished report, Geological Survey of Denmark, Copenhagen.

Lapo, A.V. \& Drozdova, I.N. 1989: Phyterals of humic coals in the USSR. International Journal of Coal Geology 12, 477-510.

Liboriussen, J., Ashton, P. \& Tygesen, T. 1987: The tectonic evolution of the Fennoscandian Border Zone in Denmark. In: Ziegler, P.A. (ed.): Compressional intra-plate deformations in the Alpine Foreland. Tectonophysics 137, 21-29.

Lottes, A.L. \& Ziegler, A.M. 1994: World peat occurrence and the seasonality of climate and vegetation. Palaeogeography, Palaeoclimatology, Palaeoecology 106, 23-37.

McCabe, P.J. 1991: Tectonic controls on coal accumulation. Bulletin de la Société Géologique de France 162, 277-282.

Michelsen, O. 1975: Lower Jurassic biostratigraphy and ostracods of the Danish Embayment. Danmarks Geologiske Undersøgelse II. Række 104, 287 pp.

Michelsen, O. 1978: Stratigraphy and distribution of Jurassic deposits of the Norwegian-Danish Basin. Danmarks Geologiske Undersøgelse Serie B 2, 28 pp

Michelsen, O. 1989: Log-sequence analysis and environmental aspects of the Lower Jurassic Fjerritslev Formation in the Danish Subbasin. Danmarks Geologiske Undersøgelse Serie A 25, 23 pp.

Michelsen, O. \& Nielsen, L.H. 1991: Well records on the Phanerozoic stratigraphy in the Fennoscandian Border Zone, Denmark. Hans-1, Sæby-1, and Terne-1 wells. Danmarks Geologiske Undersøgelse Serie A 29, 37 pp.

Michelsen, O. \& Nielsen, L.H. 1993: Structural development of the Fennoscandian Border Zone, offshore Denmark. Marine and Petroleum Geology 10, 124-134.

Michelsen, O., Nielsen, L.H., Johannessen, P.N., Andsbjerg, J. \& Surlyk, F. 2003: Jurassic lithostratigraphy and stratigraphic development onshore and offshore Denmark. In: Ineson, J.R. \& Surlyk, F. (eds): The Jurassic of Denmark and Greenland. Geological Survey of Denmark and Greenland Bulletin 1, 147-216 (this volume).

Mogensen, T.E. 1994: Palaeozoic structural development along the 
Tornquist Zone, Kattegat area, Denmark. In: Cloetingh, S. et al . (eds): Dynamics of extensional basin formation and inversion. Tectonophysics 240, 191-214.

Möller, H. 1903: Bidrag til Bornholms fossile flora, (Rhät och Lias). Gymnospermer. Kungliga Svenska Vetenskapsakademins Handlingar 36, 56 pp.

Moore, T.A., Shearer, J.C. \& Miller, S.L. 1996: Fungal origin of oxidised plant material in the Palangkaraya peat deposit, Kalimantan Tengah, Indonesia: Implications for "inertinite" formation in coal. International Journal of Coal Geology 30, 1-23.

Nielsen, L.H. 1995: Genetic stratigraphy of Upper Triassic - Middle Jurassic deposits of the Danish Basin and the Fennoscandian Border Zone 2, 3, 162 pp. Unpublished Ph.D. thesis, University of Copenhagen, Denmark.

Nielsen, L.H. 2003: Late Triassic - Jurassic development of the Danish Basin and the Fennoscandian Border Zone, southern Scandinavia. In: Ineson, J.R. \& Surlyk, F. (eds): The Jurassic of Denmark and Greenland. Geological Survey of Denmark and Greenland Bulletin 1, 459-526 (this volume).

Norling, E. \& Bergström, J. 1987: Mesozoic and Cenozoic tectonic evolution of Scania, southern Sweden. In: Ziegler, P.A. (ed.): Compressional intra-plate deformations in the Alpine Foreland. Tectonophysics 137, 7-19.

Norling, E., Ahlberg, A., Erlström, M. \& Sivhed, U. 1993: Guide to the Upper Triassic and Jurassic geology of Sweden. Sveriges Geologiska Undersökning Serie Ca 82, 71 pp.

Parrish, J.T., Ziegler, A.M. \& Scotese, C.R. 1982: Rainfall patterns and the distribution of coals and evaporites in the Mesozoic and Cenozoic. Palaeogeography, Palaeoclimatology, Palaeoecology 40, 67-101.

Peters, K.E. \& Moldowan, M. 1993: The biomarker guide - interpreting molecular fossils in petroleum and ancient sediments, 363 pp. New Jersey: Prentice Hall.

Petersen, H.I. 1993: Petrographic facies analysis of Lower and Middle Jurassic coal seams on the island of Bornholm, Denmark. International Journal of Coal Geology 22, 189-216.

Petersen, H.I. 1994: Depositional environments of coals and associated siliciclastic sediments in the Lower and Middle Jurassic of Denmark. The Øresund-5, -7, -13, -15 and -18 wells. Danmarks Geologiske Undersøgelse Serie A 33, 55 pp.

Petersen H.I. \& Andsbjerg, J. 1996: Organic facies development within Middle Jurassic coal seams, Danish Central Graben, and evidence for relative sea-level control on peat accumulation in a coastal plain environment. Sedimentary Geology 106, 259-277.

Petersen, H.I. \& Nielsen, L.H. 1995: Controls on peat accumulation and depositional environments of a coal-bearing coastal plain succession of a pull-apart basin; a petrographic, geochemical and sedimentological study, Lower Jurassic, Denmark. International Journal of Coal Geology 27, 99-129.

Petersen, H.I., Bojesen-Koefoed, J.A., Nytoft, H.P., Surlyk, F., Therkelsen, J. \& Vosgerau, H. 1998: Relative sea-level changes recorded by paralic liptinite-enriched coal facies cycles, Middle Jurassic Muslingebjerg Formation, Hochstetter Forland, Northeast Greenland. International Journal of Coal Geology 36, 1-30.

Petersen, H.I., Nielsen, L.H., Bidstrup, T. \& Thomsen, E. 2003: Burial depth and post-Early Cretaceous uplift of Lower-Middle
Jurassic strata in the Fennoscandian Border Zone based on organic maturity. In: Ineson, J.R. \& Surlyk, F. (eds): The Jurassic of Denmark and Greenland. Geological Survey of Denmark and Greenland Bulletin 1, 611-630 (this volume).

Phillips, S. \& Bustin, R.M. 1996a: Sulfur in the Changuinola peat deposit, Panama, as an indicator of the environments of deposition of peat and coal. Journal of Sedimentary Research 66, 184-196.

Phillips, S. \& Bustin, R.M. 1996b: Sedimentology of the Changuinola peat deposit: organic and clastic sedimentary response to punctuated coastal subsidence. Geological Society of America Bulletin 108, 794-814.

Pieńkowski, G. 1991: Eustatically-controlled sedimentation in the Hettangian-Sinemurian (Early Jurassic) of Poland and Sweden. Sedimentology 38, 503-518.

Pierce, B.S., Eble, C.F. \& Stanton, R.W. 1995: Comparison of the petrography, palynology, and paleobotany of the Little Fire Creek coal bed, southwestern Virginia, U.S.A. Organic Geochemistry 22, 51-71.

Rolle, F., Koch, J.-O., Frandsen, N. \& Surlyk, F. 1979: Jurassic environments in the Fenno-Scandian Border Zone. Symposium on 'Sédimentation jurassique W. européen'. Association Sedimentologie Francais Publication Spéciale 1, 15-31.

Ryer, T.A. \& Langer, A.W. 1980: Thickness change involved in the peat-to-coal transformation for a bituminous coal of Cretaceous age in central Utah. Journal of Sedimentary Petrology $\mathbf{5 0}$ 987-992.

Scotese, C.R. 1994: Early and Middle Jurassic maps. In: Klein, G.H. (ed.): Pangea: Paleoclimate, tectonics, and sedimentation during accretion, zenith, and breakup of a supercontinent. Geological Society of America Special Paper 288.

Scott, A.C. 1989: Observations on the nature and origin of fusain. International Journal of Coal Geology 12, 443-475.

Scott, A.C. 1991: An introduction to the applications of palaeobotany and palynology to coal geology. Bulletin de la Société Géologique de France 162, 145-153.

Sellwood, B.W. 1972: Tidal-flat sedimentation in the Lower Jurassic of Bornholm, Denmark. Palaeogeography, Palaeoclimatology, Palaeoecology 11, 93-106.

Sivhed, U. 1984: Litho- and biostratigraphy of the Upper Triassic - Middle Jurassic in Scania, southern Sweden. Sveriges Geologiska Undersökning Serie C 806, 31 pp.

Sorgenfrei, T. \& Buch, A. 1964: Deep tests in Denmark, 1935-1959. Danmarks Geologiske Undersøgelse III. Række 36, 146 pp.

Srivastava, S.K. 1976: The fossil pollen genus Classopollis. Lethaia 9, 437-457.

Staub, J.R. \& Esterle, J.S. 1994: Peat-accumulating depositional systems of Sarawak, East Malaysia. Sedimentary Geology $\mathbf{8 9}$, 91-106.

Stewart, W.N. 1983: Paleobotany and the evolution of plants, 405 pp. Cambridge: Cambridge University Press.

Surlyk, F., Arndorff, L., Hamann, N.-E., Hamberg, L., Johannessen, P.N., Koppelhus, E.B., Nielsen, L.H., Noe-Nygaard, N., Pedersen, G.K. \& Petersen, H.I. 1995: High-resolution sequence stratigraphy of a Hettangian-Sinemurian paralic succession, Bornholm, Denmark. Sedimentology 42, 323-354.

Teichmüller, M. 1989: The genesis of coal from the viewpoint of 
coal petrology. International Journal of Coal Geology 12, 1-87. Tralau, H. 1968: Botanical investigations into the fossil flora of Eriksdal in Fyledalen, Scania. II: The middle Jurassic microflora. Sveriges Geologiska Undersökning Serie C 633, 132 pp.

Troedsson, G. 1951: On the Höganäs Series of Sweden (Rhaeto-Lias). Lunds Universitet Årsskrift Ny Följd 2 47(1), 269 pp.

Underhill, J.R. \& Partington, M.A. 1993: Jurassic thermal doming and deflation in the North Sea: Implications of sequence stratigraphic evidence. In: Parker, J.R. (ed.): Petroleum geology of Northwest Europe: proceedings of the 4th conference, 337-345. London: Geological Society.

van Konijnenburg-van Cittert, J.H.A. 1971: In situ gymnosperm pollen from the Middle Jurassic of Yorkshire. Acta Botanica Neerlandica 20, 96 pp.

van Konijnenburg-van Cittert, J.H.A. 1978: Osmundaceous spores in situ from the Jurassic of Yorkshire, England. Review of Palaeobotany and Palynology 26, 125-142.

Vejbæk, O.V. 1985: Seismic stratigraphy and tectonics of sedi- mentary basins around Bornholm, southern Baltic. Danmarks Geologiske Undersøgelse Serie A 8, 30 pp.

Waples, D.W. \& Machihara, T. 1991: Biomarkers for geologists a practical guide to the application of steranes and triterpanes in petroleum geology. American Association of Petroleum Geologists Methods in Exploration Series 9, 91 pp.

Ziegler, A.M., Raymond, A.L., Gierlowski, T.C., Horrell, M.A., Rowley, D.B. \& Lottes, A.L. 1987: Coal, climate and terrestrial productivity: the present and the early Cretaceous compared. In: Scott, A.C. (ed.): Coal and coal-bearing strata: recent advances. Geological Society Special Publication (London) 32, 25-49.

Ziegler, P.A. 1982: Geological atlas of western and central Europe, 130 pp. The Hague: Elsevier for Shell Internationale Petroleum Maatschappij.

Ziegler, P.A. 1988: Evolution of the Arctic - North Atlantic and the western Tethys. American Association of Petroleum Geologists Memoir 43, 179 pp.

Manuscript received 12 January 1996; revision accepted 13 January 1998. 